\title{
Review
}

\section{Structural studies of large nucleoprotein particles, vaults}

\author{
By Hideaki TANAKA ${ }^{* 1, * 2}$ and Tomitake TsukIHARA ${ }^{* 1, * 3, \dagger}$
}

(Communicated by Shigekazu NAGATA, M.J.A.)

\begin{abstract}
Vault is the largest nonicosahedral cytosolic nucleoprotein particle ever described. The widespread presence and evolutionary conservation of vaults suggest important biologic roles, although their functions have not been fully elucidated. X-ray structure of vault from rat liver was determined at $3.5 \AA$ resolution. It exhibits an ovoid shape with a size of $40 \times 40 \times 67 \mathrm{~nm}^{3}$. The cage structure of vault consists of a dimer of half-vaults, with each half-vault comprising 39 identical major vault protein (MVP) chains. Each MVP monomer folds into 12 domains: nine structural repeat domains, a shoulder domain, a cap-helix domain and a cap-ring domain. Interactions between the 42-turn-long cap-helix domains are key to stabilizing the particle. The other components of vaults, telomerase-associated proteins, poly(ADP-ribose) polymerases and small RNAs, are in location in the vault particle by electron microscopy.
\end{abstract}

Keywords: a large protein complex, X-ray structure

\section{Introduction}

Vaults are large, ovoid ribonucleoprotein particles that were discovered in 1986 as contaminants in preparations of clathrin-coated vesicles from rat liver tissues. ${ }^{1)}$ These ovoid bodies were also present in preparations of coated vesicles that had been treated with $2 \mathrm{M}$ urea to remove clathrin triskelions, suggesting that the bodies were more stable than the coated vesicles. The particles were purified using sucrose density gradients and agarose gel electrophoresis, revealing symmetric, barrel-shaped structures that resembled the ceilings of gothic cathedrals. Based on their morphology, the bodies were named vaults. Vaults were first determined

*1 Institute for Protein Research, Osaka University, Osaka, Japan.

2 PRESTO, JST, Saitama, Japan.

*3 Department of Life Science, University of Hyogo, Hyogo, Japan.

$\dagger$ Correspondence should be addressed: T. Tsukihara, Department of Life Science, University of Hyogo, 3-2-1 Koto, Kamighori, Akoh, Hyogo 678-1297, Japan (e-mail: tsuki@protein. osaka-u.ac.jp).

Abbreviations: CFTR: cystic fibrosis transmembrane conductance regulator; EGF: epidermal growth factor; MVP: major vault protein, NCS: noncrystallographic symmetry; NMR: nuclear magnetic resonance; VPARP: vault poly(ADP-ribose) polymerase; SPFH: stomatin-prohibitin-flotillin-HflK-C; PEG: polyethylene glycol; vRNA: Vault RNA; SH2: Src homology 2; TEP1: telomerase-associated protein 1 ; IFN- $\gamma$ : interferon $\gamma$. to be $35 \times 35 \times 65 \mathrm{~nm}^{3}$ in size, ${ }^{1)}$ and then, using cryoelectron microscopy, were shown to be $41 \times 41 \times$ $72.5 \mathrm{~nm}^{3}$, making them the largest nonicosahedral cytosolic nucleoprotein particles ever described. ${ }^{2)}$ Vaults have been identified in a wide variety of species, including mammals, birds, fish, echinoids and slime molds. ${ }^{3)}$ Extensive structural and functional studies have been performed, particularly by the group that first discovered vaults led by L.H. Rome. The widespread presence and evolutionary conservation of vaults suggest important biological roles, although their functions have not been fully elucidated.

The first structural studies of these large nucleoprotein complexes were performed using electron microscopy, which were followed by X-ray crystallographic and solution nuclear magnetic resonance (NMR) analyses. In 2009, we successfully determined the structure of vault from rat liver at $3.5 \AA$ resolution after a number of trials to crystallize the particles. ${ }^{4)}$ This paper describes the structure of vault elucidated based on X-ray crystallography and electron microscopy.

\section{Composition of vault}

SDS PAGE analysis identified four proteins with relative molecular masses of 210,000, 192,000, 104,000, and 54,000, and a small RNA with a relative molecular mass of 37,000 as components of rat vault. 
The major vault protein (MVP) has a relative molecular mass of 104,000 and accounts for $>70 \%$ of the total protein. ${ }^{1)}$ The protein with a relative molecular mass of 54,000 was determined to be a breakdown product of MVP. ${ }^{3)}$ Highly similar to the catalytic domain of poly(ADP-ribose) polymerase (PARP), the 193-kD protein (VPARP; formerly $192 \mathrm{kD}$ ) catalyzes a polyADP-ribosylation reaction. ${ }^{5)}$ The $240-\mathrm{kDa}$ vault protein (formerly $210 \mathrm{kDa}$ ) was found to be identical to the mammalian telomeraseassociated component. ${ }^{6}$ Vaults also contain small untranslated RNA molecules (vRNA, 88-141 bases), which account for $4.6 \%$ of the particle weight. ${ }^{1,7)}$ Humans express the hvg1, hvg2 and hvg3 vRNA genes, resulting in products with 98,88 and 88 bases, respectively. ${ }^{8)}$ The bulk of vRNA in the particles is hvg1. Mammalian vaults, therefore, are composed of MVP, telomerase-associated protein 1 (TEP1), VPARP and vRNA. Each vault particle is thought to contain two copies of TEP1 and eight copies of VPARP. ${ }^{9)}$ Densitometric analysis of Coomassie Brilliant Blue-stained samples indicated that MVP accounts for $74.6 \%$ of the total mass of the particles, including vRNA. ${ }^{10)}$ Scanning transmission electron microscopy showed that vault particles have a mass of $12.9 \pm 1 \mathrm{MDa}$. This value was consistent with the sedimentation behavior of vault particles on velocity sucrose gradients.

The molecular weights of mammalian vault components estimated from their sequences are listed in Table 1. Two different structures of rat vault were reported as described below. One contains 78 molecules of MVP, whereas the other includes 96 MVP molecules. Because $95.8-\mathrm{kD}$ MVP is $74.6 \%$ of the total particle mass, the total molecular weights of the $78 \mathrm{mer}$ and $96 \mathrm{mer}$ are 10.0 MDa and 11.8 MDa, respectively.

\section{Proposed functional roles of vault}

Several roles for vaults have been proposed. Chugani et al. ${ }^{16)}$ suggested that vaults serve as the central plug in nuclear pore complexes. The authors confirmed the cellar localization of vaults using immunofluorescence approaches and immunoelectron microscopy. Immunofluorescence analysis with antivault antibodies showed that vaults were located on surface of the nuclear envelope in isolated rat liver nuclei. Immunoelectron microscopy with gold-conjugated secondary antibodies indicated that vaults associated with nuclear pore complexes in isolated nuclei. Thus, vaults may contribute to nucleocytoplasmic transport.
Table 1. Vault components

\begin{tabular}{lccc}
\hline & $\begin{array}{c}\text { Numbers of residues } \\
\text { or bases }\end{array}$ & $\begin{array}{c}\text { Molecular weight } \\
(\mathrm{kDa})\end{array}$ & Ref. \\
\hline MVP & 861 & 95,798 & 11 \\
rat & 893 & 99,327 & 12 \\
human & & & \\
vPARP & 1,724 & 192,595 & 5 \\
human & & & \\
TEP1 & & & 6,13 \\
rat & 2,629 & 291,708 & 6,14 \\
human & 2,627 & 290,490 & \\
& & & 15 \\
vRNA & 141 & & \\
rat & & 47,686 & \\
human & 98 & 29,994 & \\
hvg1 & & 29,612 & \\
hvg2 & & & \\
hvg3 & & & \\
\hline
\end{tabular}

In the $1990 \mathrm{~s}$, some reports proposed that vaults may be directly involved in multidrug resistance. Scheffer et al. isolated and sequenced cDNA encoding a protein associated with multidrug resistance termed Lung Resistance-related Protein, which is now known to be human MVP. ${ }^{12}$ Kitazono et al. confirmed the relationship between multidrug resistance and vault using SW-620 human colon carcinoma cells. ${ }^{17)}$ Treating SW-620 cells with sodium butyrate induced MVP expression and conferred resistance to doxorubicin, vincristine, etoposide, gramicidin D and paclitaxel. Transfecting the cells with MVP-specific ribozymes inhibited these activities. Furthermore, the authors examined doxorubicin efflux in cells or isolated nuclei using fluorescence microscopy. In cells treated with sodium butyrate, doxorubicin left the nuclei more rapidly than results observed with ribozyme-transfected cells.

In 2005, Gopinath et al. suggested that human hvg1 and hvg2 vRNA can bind the anticancer drug mitoxantrone and may play an important role in exporting toxic compounds. ${ }^{18)}$ In contrast, Mossink et al. showed that disrupting the murine MVP gene did not result in sensitivity to cytostatic drugs; ${ }^{19)}$ the sensitivities of $\mathrm{MVP}^{+/+}$and $M V \mathrm{P}^{-/-}$embryonic stem cells to chemotherapeutic drugs were not significantly different. Furthermore, wild-type and MVP-deficient mice responded similarly to doxorubicin. Huffman and Corey showed that knocking 
down MVP expression using small interfering RNA did not affect the removal of doxorubicin from nuclei of resistant cells. ${ }^{20)}$ In addition, upregulation of MVP expression in chemosensitive cells did not increase drug resistance. These results indicate that MVP and vault particles are not directly involved in resistance to cytostatic agents.

A number of more recent studies have described roles for vault particles in various cell signaling pathways. $\mathrm{Yu}$ et al. identified MVP as a PTENbinding protein in a yeast two-hybrid screen. ${ }^{21)}$ PTEN is a tumor suppressor that dephosphorylates phosphatidylinositol 3,4,5-trisphosphate to downregulate phosphoinositide 3-kinase/Akt-mediated signaling. PTEN also regulates cell growth, adhesion, migration, invasion and apoptosis. A yeast twohybrid screen suggested that the N-terminal phosphoinositide binding motif and C2 domain of PTEN interacted with two putative $\mathrm{EF}$ hand domains of MVP (amino acid residues 113-222); these interactions required calcium ions. X-ray structures ${ }^{4), 22)}$ and NMR solution structure, ${ }^{23)}$ which include the R3 and R4 structural repeat domains, did not show EF hand domains. Kolli et al. found that MVP is a substrate for the Src homology 2 (SH2) domain-containing tyrosine phosphatase SHP-2 and acts as scaffold protein during epidermal growth factor (EGF) signaling. ${ }^{24)}$ The authors showed that the SH2 domains of SHP-2 associated with tyrosyl-phosphorylated MVP, and this association was enhanced by EGF. Furthermore, phosphorylated MVP interacted with the activated form of extracellularregulated kinases in response to EGF. Thus, MVP functions as a scaffold protein for SHP-2 and extracellular-regulated kinases, and regulation of MVP phosphorylation by SHP-2 may play an important role in cell survival. Kim et al. performed pull-down assays using GST-Src-SH2 fusion proteins, revealing an interaction between $\mathrm{MVP}$ and the $\mathrm{SH} 2$ domain of Src in human stomach tissue and 253J stomach cancer cells. ${ }^{25)}$ Immunoprecipitation and immunofluorescence analyses indicated that EGF enhanced the interaction between MVP and Src, and this interaction was blocked by the Src kinase inhibitor PP2. EGF also triggered the translocation of MVP from the nucleus to the cytosol and perinuclear region where MVP colocalized with Src. MVP was also proposed as a novel regulator of Srcmediated signaling cascades. Steiner et al. identified MVP as an interferon $\gamma($ IFN- $\gamma)$-inducible protein $;{ }^{26)}$ significant increases in MVP mRNA and protein levels was observed in response to IFN- $\gamma$. This activation involved an interaction between STAT1 and an IFN- $\gamma$-activated site in the proximal MVP promoter. IFN- $\gamma$ also significantly enhanced the MVP translation rate. In MVP-negative H65 lung cancer cells, MVP expression led to reduced expression of IFN- $\gamma$-regulated genes, including ICAM-1, CD13 and CD36. MVP expression in H65 cells also significantly reduced STAT1 phosphorylation at Y701 and decreased the translocation of STAT1 into nuclei. The authors concluded that vault particles function as a general interaction platform for cellular signaling cascades.

In 2007, two research groups reported that vault particles contributed to responses to infections. Mrázek et al. developed a novel experimental strategy called subtractive hybridization of noncoding RNA transcripts to specifically select and amplify regulatory noncoding $\mathrm{RNA}^{27)}$ The authors used this method to examine human B cells infected with Epstein-Barr virus and found increased levels of three host cell-encoded vRNAs in the infected cells, suggesting that vRNAs may be involved in antiviral defense and/or transport mechanisms. Kowalski et al. reported that MVP was rapidly recruited to lipid rafts when human lung epithelial cells were infected with Pseudomonas aeruginosa. ${ }^{28}$ Interestingly, cystic fibrosis transmembrane conductance regulator (CFTR), which is located in lipid rafts, acts as a receptor for an outer core oligosaccharide from the $P$. aeruginosa lipopolysaccharide; binding leads to rapid innate immune responses, including epithelial cell ingestion of bacteria, nuclear factor $\kappa \mathrm{B}$ activation, cytokine secretion and eventual epithelial cell apoptosis. Matrix-assisted laser desorption/ ionization-time-of-flight mass spectrometry was used to identify 150 proteins, including MVP, that were recruited to lipid rafts in human lung epithelial cells 15 min after infection with $P$. aeruginosa. MVP was also detected in lipid rafts using immunoblot and fluorescence microscopic analyses. To further examine the potential roles of MVP in host resistance to bacteria, wild-type and $\mathrm{MVP}^{-/-}$mice were infected with $\sim 1.5 \times 10^{7} \mathrm{PA} 01-\mathrm{V} P$. aeruginosa cells. Compared with wild-type mice, $\mathrm{MVP}^{-/-}$mice showed reduced lung epithelial cell internalization and clearance of the bacteria, and a 3.5-fold increase in the number of bacteria per gram of lung tissue. Overall, the lack of MVP increased mortality associated with $P$. aeruginosa infections. Thus, the authors showed that CFTR-dependent recruitment of MVP to rafts after $P$. aeruginosa infection facilitates innate immune responses to this pathogen. 


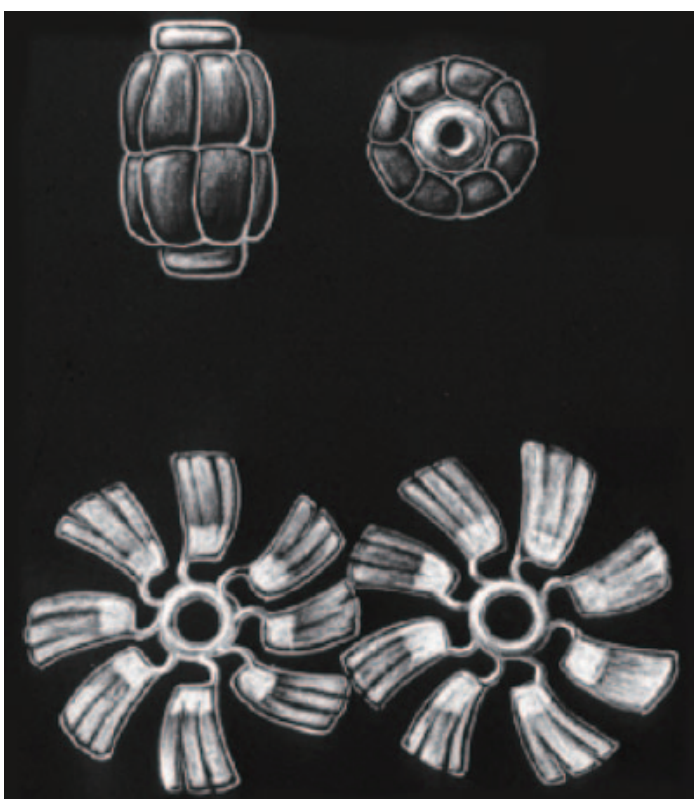

Fig. 1. Structural models of vault particles based on electron microscopic analyses. ${ }^{10)}$ Top row, Side (left) and top views (right) of intact vault particles. Bottom row, Paired vault flowers derived from a single vault particle. Figures are reproduced from Kedersha et al. ${ }^{10)}$ with copyright permission from the Rockefeller University Press.

\section{Electron microscopic analysis of closed and open vault structures}

A variety of electron microscopic techniques have been used to study the structures of vault particles. ${ }^{10)}$ One model is a hollow, barrel-like structure belonging to the $\mathrm{D}_{8}$ point group, which requires MVP. A freeze-etch procedure revealed a flower-like structure for vault. The flowers were usually observed in pairs, suggesting that vault particles contained two folded flowers. Each flower was composed of eight rectangular petals surrounding a central ring, with the corner of each petal connected to the ring by a thin, short hook. Models of the barrel-like and flower-like structures are shown in Fig. 1.

A three-dimensional cryoelectron microscopic reconstruction of rat vault with imposed C8 symmetry at $31 \AA$ resolution provided a clear image of the particles. ${ }^{29)}$ Each particle has a smooth outer shell with a barrel-shaped central area and two protruding caps. The maximum dimensions of vault are $420 \AA \times$ $750 \AA$. The barrel has an invaginated waist that is $380 \AA$ in diameter and the two end caps have maximum diameters of $240 \AA$. The majority of each vault particle has a wall thickness of $\sim 25 \AA$.
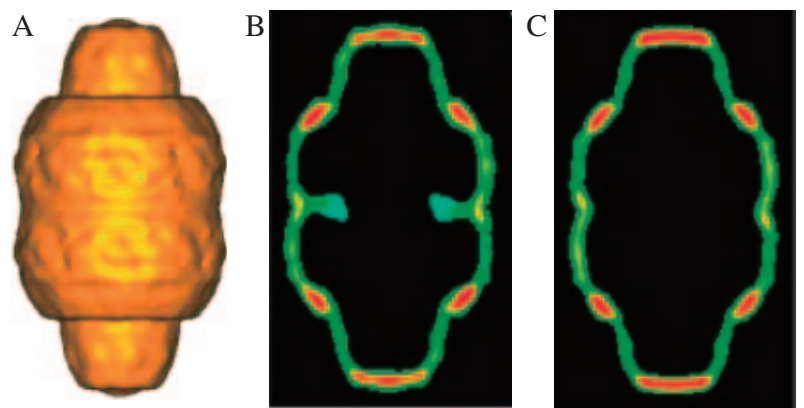

Fig. 2. Cryoelectron microscopic analyses of wild-type vault and vault containing recombinant HisT7-MVP. (A) An isosurface representation of recombinant vault containing HisT7-MVP and (B) a density slice of the image. (C) A density slice of an image of wild-type vault. The two density slices are displayed using the same color map, with stronger densities in red, weaker densities in light blue, and densities at or below background noise in black. Note the weakly dense area in (B) protruding from the inner surface at the central constriction of the particle containing HisT7-MVP. Figures are reproduced from Mikyas et al. ${ }^{2)}$ with copyright permission from Elsevier.

Comparing reconstructed densities of wild-type vault and recombinant vaults with $\mathrm{N}$-terminal peptide tags on MVP revealed that the MVP $\mathrm{N}$ termini were located at the inner surface of the vault central area (Fig. 2). ${ }^{2)}$

\section{X-ray crystallography of the vault structure}

Crystallization of vault. Several groups have crystallized vault particles to help elucidate their functions. All reported crystals of vault and the individual components are listed in Table 2. The first vault crystal was obtained from a human astrovirus preparation from which vault particles were copurified with the virus. ${ }^{22)}$ The crystals were triangular and reached approximately $0.15 \times 0.15 \times 0.02 \mathrm{~mm}^{3}$ in size. Similar vault crystals were obtained from the sample purified from the same cells in the absence of virus. Vault from rat liver and several recombinant vault particles have been crystallized as well. ${ }^{30)} \mathrm{X}$-ray diffraction data from crystals consisting of recombinant MVP were obtained at $9 \AA$ resolution. After examining various crystallization conditions for vault from rat liver, we obtained several different crystals (Fig. 3). These crystals, however, diffracted x-rays at resolutions as high as $8 \AA .{ }^{31)}$ When a form VI crystal belonging to the $P 2_{1}$ space group was soaked in buffer solution containing $34 \%(\mathrm{v} / \mathrm{v})$ PEG as cryoprotectant, it became a form VIa crystal and diffracted Xrays at $3.2 \AA$ resolution. ${ }^{4)}$ The VIa and VIc crystals both belonged to the $C 2$ space group and had similar 
Table 2. Crystals of vaults and MVP domains

\begin{tabular}{|c|c|c|c|c|c|c|c|}
\hline Substance & Source & Crystallization conditions & $\begin{array}{l}\text { Shape and size } \\
\left(\mathrm{mm}^{3}\right)\end{array}$ & Unit cell & $\begin{array}{l}\mathrm{dmin} \\
(\AA)\end{array}$ & Form & Ref. \\
\hline vault & monkey cells & $\begin{array}{l}800 \mathrm{mM} \mathrm{NaCl}, 50 \mathrm{mM} \mathrm{Li}_{2} \mathrm{SO}_{4}, \\
4 \% \mathrm{PEG} 4 \mathrm{~K}, 50 \mathrm{mM} \text { Tris-buffer, } \\
\mathrm{pH} 8 .\end{array}$ & $\begin{array}{l}\text { triangular prism, } \\
0.15 \times 0.15 \times 0.02\end{array}$ & $R 32, a=b=c=450 \AA$ & 10.0 & I & 22 \\
\hline $\begin{array}{l}\text { MVP with } \\
\text { cyst-tag }\end{array}$ & $\begin{array}{l}\text { Rat } \\
\text { recombinant }\end{array}$ & $\begin{array}{l}0.64 \%-0.76 \% \text { PEG } 8 \mathrm{~K}, 3 \% \text { glycerol, } \\
0.044 \mathrm{M} \mathrm{MgCl}_{2}, 0.2 \% \beta-\mathrm{OG}^{*} \\
0.05 \mathrm{M} \mathrm{Na} \text { MOPS, pH } 7\end{array}$ & & $\begin{array}{l}C 2, a=631.5, b=464.7 \\
c=584.6 \AA, \beta=123.8^{\circ}\end{array}$ & 9.0 & II & 30 \\
\hline vault & rat & $\begin{array}{l}15 \% \mathrm{PEG} 400,0.8 \mathrm{M} \mathrm{NaCl}, \\
50 \mathrm{mM} \mathrm{Li}_{2} \mathrm{SO}_{4}, 50 \mathrm{mM} \text { Tris- } \mathrm{HCl}, \\
\mathrm{pH} 8.0\end{array}$ & $\begin{array}{l}\text { parallelepiped plate } \\
0.35 \times 0.30 \times 0.10\end{array}$ & & & III & 31 \\
\hline vault & rat & $\begin{array}{l}4 \% \text { PEG } 4000,50 \mathrm{mM} \mathrm{KCl}, 25 \% \mathrm{EG}^{* *} \\
50 \mathrm{mM} \text { Tris- } \mathrm{HCl}, \mathrm{pH} 7.0\end{array}$ & $\begin{array}{l}\text { parallelepiped } \\
\text { column } \\
0.07 \times 0.07 \times 0.30\end{array}$ & $\begin{array}{l}P 1 a=442.0, b=598.7 \\
c=638.9 \AA, \alpha=68.1 \\
\beta=78.2, \gamma=70.3^{\circ}\end{array}$ & 10.0 & IV & 31 \\
\hline vault & rat & $\begin{array}{l}4 \% \text { PEG } 2000,50 \mathrm{mM} \mathrm{KCl}, 25 \% \text { EG, } \\
50 \mathrm{mM} \text { Tris-HCl, pH } 7.0\end{array}$ & $0.10 \times 0.05 \times 0.30$ & $\begin{array}{l}P 2_{1}, a=390, b=545 \\
c=672 \AA, \beta=94^{\circ}\end{array}$ & & $\mathrm{V}$ & 31 \\
\hline vault & rat & $\begin{array}{l}2.4 \% \mathrm{PEG} 4000,0.8 \mathrm{M} \mathrm{NaCl}, \\
50 \mathrm{mM} \mathrm{Li}_{2} \mathrm{SO}_{4}, 50 \mathrm{mM} \text { Tris-HCl, } \\
\mathrm{pH} 8.0\end{array}$ & $\begin{array}{l}\text { elongated } \\
\text { parallelepiped plate } \\
0.10 \times 0.25 \times 1.00\end{array}$ & $\begin{array}{l}P 2_{1}, a=599.8, b=385.0 \\
c=616.4 \AA, \beta=109.1^{\circ}\end{array}$ & 8.0 & VI & 31 \\
\hline vault & rat & $\begin{array}{l}2.4 \% \mathrm{PEG} 4000,0.8 \mathrm{M} \mathrm{NaCl}, \\
50 \mathrm{mM} \mathrm{Li}_{2} \mathrm{SO}_{4}, 50 \mathrm{mM} \text { Tris- } \mathrm{HCl}, \mathrm{pH} 8.0 \\
\text { crystals are soaked in cryoprotectant } \\
\text { with another buffer condition*** }\end{array}$ & $\begin{array}{l}\text { elongated } \\
\text { parallelepiped plate } \\
0.10 \times 0.25 \times 1.00\end{array}$ & $\begin{array}{l}C 2, a=702.2, b=383.8 \\
c=598.5 \AA, \beta=124.7^{\circ}\end{array}$ & 3.2 & VIa & $\begin{array}{l}31 \\
4\end{array}$ \\
\hline vault & rat & & & $\begin{array}{l}P 2_{1}, a=601.1, b=386.6, \\
c=627.1 \AA, \beta=108.6^{\circ}\end{array}$ & 8.0 & VIc & 32 \\
\hline vault & rat & 2 & & $\begin{array}{l}C 2, a=726.2, b=391.4 \\
c=607.6 \AA, \beta=124.1^{\circ}\end{array}$ & 10.0 & VId & 32 \\
\hline vault & rat & $\begin{array}{l}4 \% \text { PEG } 3350,50 \mathrm{mM} \text { ammonium } \\
\text { acetate, } 25 \% \mathrm{EG}\end{array}$ & $\begin{array}{l}\text { tetragonal bipyramid } \\
0.08 \times 0.08 \times 0.08\end{array}$ & $\begin{array}{l}P 4, a=b=625 \\
c=767 \AA\end{array}$ & & VII & 31 \\
\hline vault & rat & $\begin{array}{l}3 \% \text { PEG } 8000,50 \mathrm{mM} \mathrm{KCl}, 25 \% \text { EG, } \\
50 \mathrm{mM} \text { Tris-HCl, pH } 7.0\end{array}$ & $\begin{array}{l}\text { Parallelepiped plate } \\
0.15 \times 0.10 \times 0.02\end{array}$ & & & VIII & 31 \\
\hline $\begin{array}{l}\text { MVP } \\
\text { N-terminal } \\
\text { domains }\end{array}$ & $\begin{array}{l}\text { Mus } \\
\text { musculus } \\
\text { recombinant }\end{array}$ & & & $\begin{array}{l}P 1, a=29.39, b=50.79 \\
c=76.85 \AA, \alpha=104.32 \\
\beta=92.44, \gamma=99.75^{\circ}\end{array}$ & 2.1 & IX & 32 \\
\hline $\begin{array}{l}\text { MVP } \\
\text { N-terminal } \\
\text { domains } \\
\end{array}$ & $\begin{array}{l}\text { Mus } \\
\text { musculus } \\
\text { recombinant }\end{array}$ & & & $\begin{array}{l}P 2_{1}, a=58.6, b=59.7 \\
c=68.3 \AA, \beta=95.5^{\circ}\end{array}$ & 3.0 & $\mathrm{X}$ & 32 \\
\hline $\begin{array}{l}\text { MVP } \\
\text { N-terminal } \\
\text { domains }\end{array}$ & $\begin{array}{l}\text { Mus } \\
\text { musculus } \\
\text { recombinant }\end{array}$ & & & $\begin{array}{l}P 2_{1}, a=36.5, b=98.8 \\
c=140.6 \AA, \beta=97.2^{\circ}\end{array}$ & 2.5 & $\mathrm{XI}$ & 32 \\
\hline
\end{tabular}

unit cell shapes. The unit cell volume of the VIa crystal was $93 \%$ of that of the VIc crystal. Dehydrating the crystals in buffer containing $34 \%$ PEG 400 shrunk the unit cell and improved the arrangement of molecules in the crystal. The atomic structure of the vault particles was determined using VIa crystals. ${ }^{4}$ )

The N-terminal region of mouse MVP-aminoacid residues 1-383-was expressed in E. coli cells and purified to create high-resolution crystals. An N- 


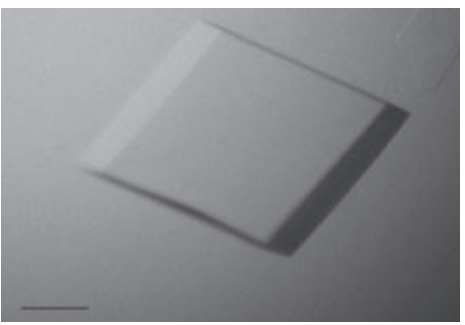

(A)

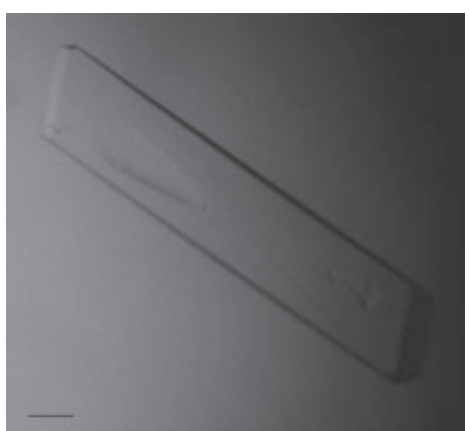

(D)

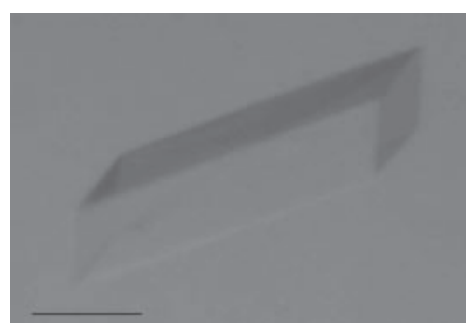

(B)

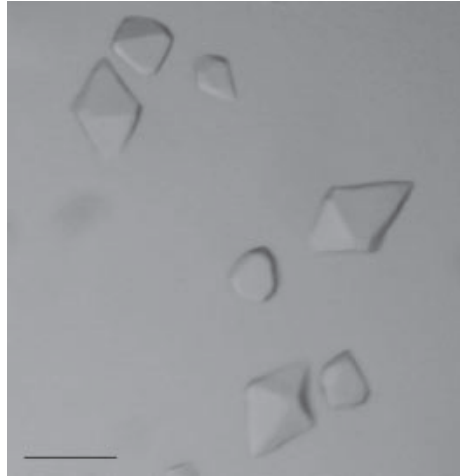

(E)

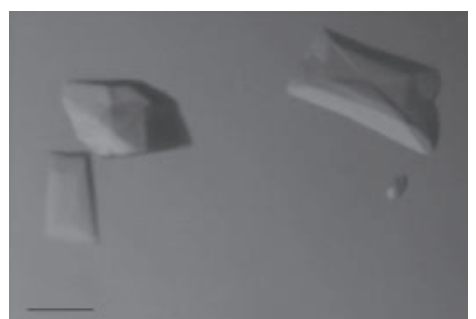

(C)

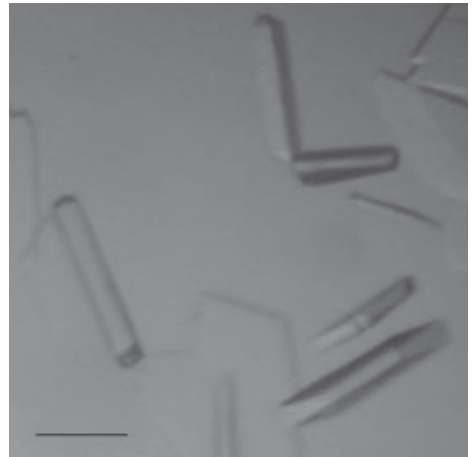

(F)

Fig. 3. Photographs of crystals of vault particles from rat liver. The various panels show different crystal forms, including (A) a crystal (form III), (B) a triclinic crystal (form IV), (C) monoclinic crystals (form V), (D) a monoclinic crystal (form VI), (E) tetragonal crystals (form VII), and (F) crystals (form VIII). Scale bars, $0.1 \mathrm{~mm}$. Figures are reproduced from Kato et al. ${ }^{31)}$ with permission of the International Union of Crystallography.

terminal peptide containing seven repeated domains was crystallized as three different species, which diffracted X-rays at resolutions of $2.1 \AA, 2.5 \AA$ and $3.0 \AA$, respectively. ${ }^{32)}$

X-ray structural analysis of vault. The crystal structure of empty vault containing a cysteine-tagged construct of MVP was analyzed at $9 \AA$ resolution by a molecular replacement method using electron density data obtained with cryoelectron microscopy. Because electron microscopy suggested that vault was characterized by 48-fold rotational symmetry, ${ }^{10)}$ the phases were refined based on density modification, including concentric 24- and 48-fold rotational symmetry averaging. Although refinement up to $9 \AA$ improved the continuous distribution of electron density, it did not reveal protein folding in each subunit in the refined map. ${ }^{30)}$

The rotational symmetry of crystallized vault was determined by X-ray structural analysis of a form VIa crystal at $10 \AA$ resolution. ${ }^{31)}$ Self-rotation functions were calculated using GLRF software. ${ }^{33)}$ Two-fold rotational symmetries are shown for $\kappa=180^{\circ}$ sections of stereo diagrams (Fig. 4). Multiple two-fold symmetry axes were perpendicular to the rotation axis at $(\varphi, \psi)=\left(110^{\circ}, 90^{\circ}\right)$. The rotation

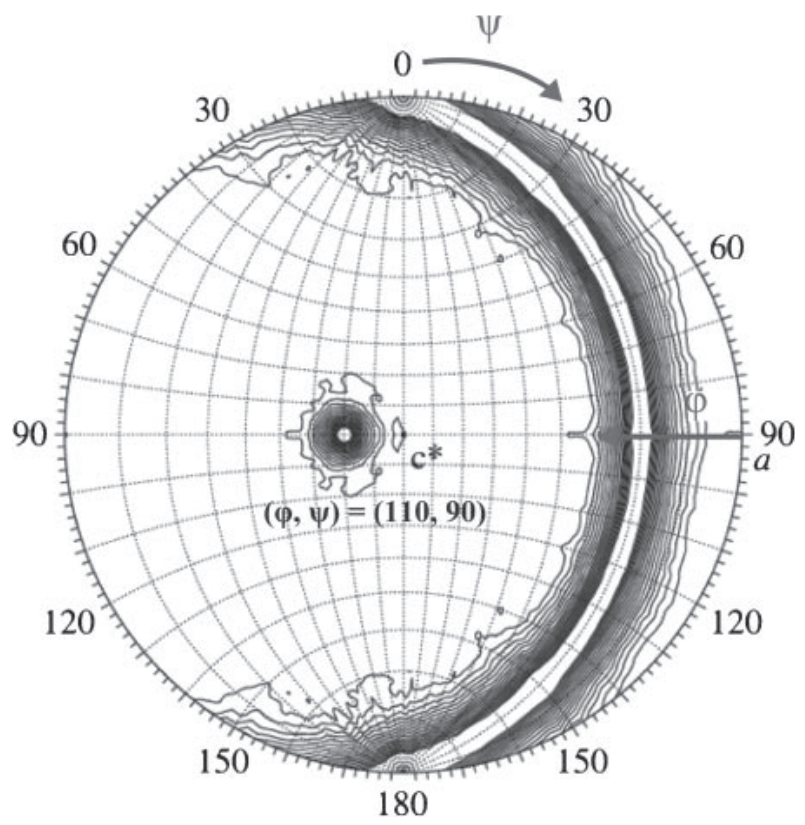

Fig. 4. Stereo diagrams based on the slow-rotation function for two-fold rotational symmetry $\left(\chi=180^{\circ}\right.$ section $)$ in the $50-10 \AA$ resolution range. Contours were drawn at equal intervals of $0.5 \sigma$ starting from $0.5 \sigma$. The peak at $(\varphi, \psi)=\left(110^{\circ}, 90^{\circ}\right)$ represents a multifold rotation axis. 


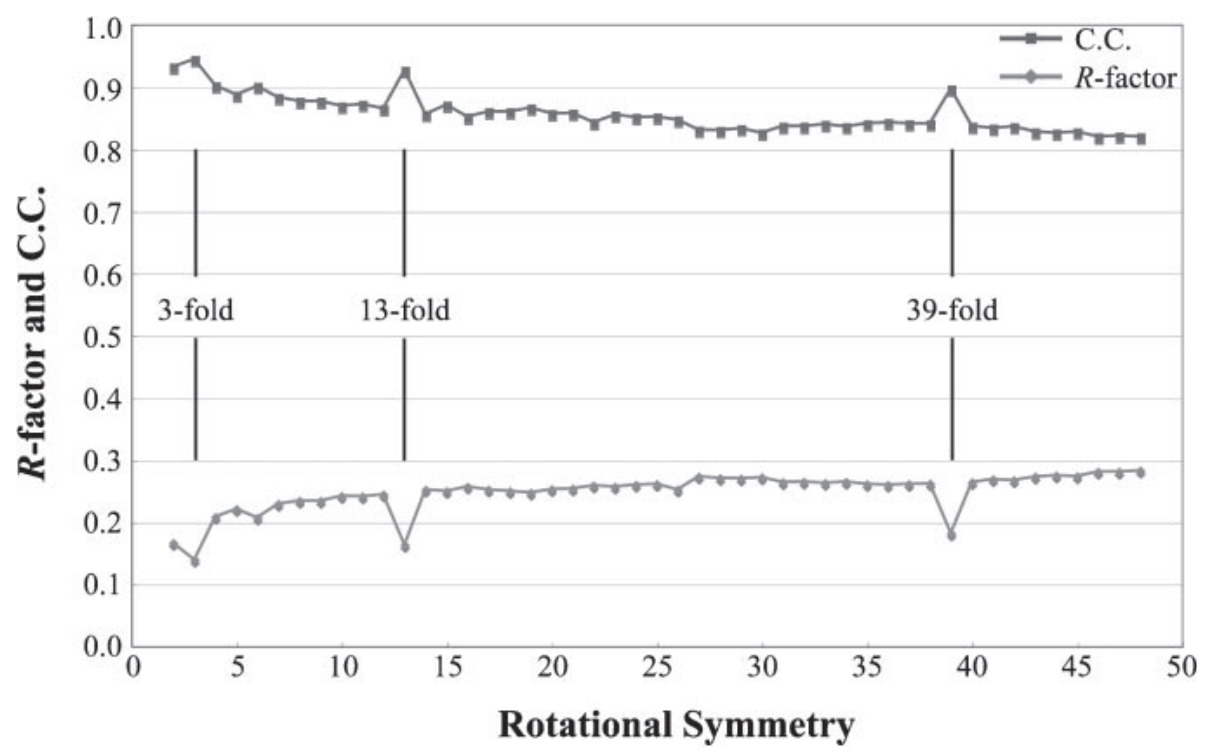

Fig. 5. $R$ factors $\left(\mathrm{a}, \quad R=\Sigma|| F_{\mathrm{O}}|-| F_{\mathrm{c}}|| / \Sigma\left|F_{\mathrm{O}}\right|\right)$ and correlation coefficients $\quad\left(\mathrm{b}, \quad \Sigma\left[\left(\left\langle\left|F_{\mathrm{O}}\right|\right\rangle-\left|F_{\mathrm{O}}\right|\right)\left(\left\langle\left|F_{\mathrm{c}}\right|\right\rangle-\left|F_{\mathrm{c}}\right|\right)\right] / \Sigma\left[\left(\left\langle\left|F_{\mathrm{O}}\right|\right\rangle-\right.\right.\right.$ $\left.\left.\left|F_{\mathrm{o}}\right|\right)^{2}\left(\langle|F \mathrm{c}|\rangle-\left|F_{\mathrm{c}}\right|\right)^{2}\right]^{1 / 2}$ plotted against various NCS averaging values at $10 \AA$ resolution. $F_{\mathrm{O}}$ and $F \mathrm{c}$ are observed and calculated structure factors, respectively, and \langle\rangle indicates an averaged value. Figures are reproduced from Kato et al. ${ }^{31)}$ with permission of the International Union of Crystallography.

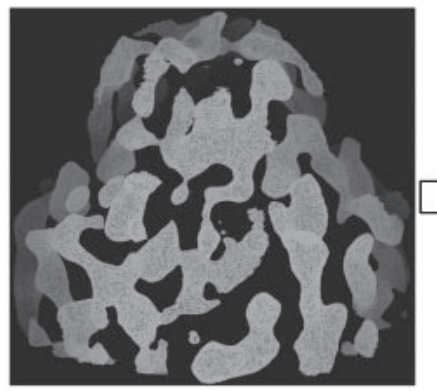

$30 \AA$

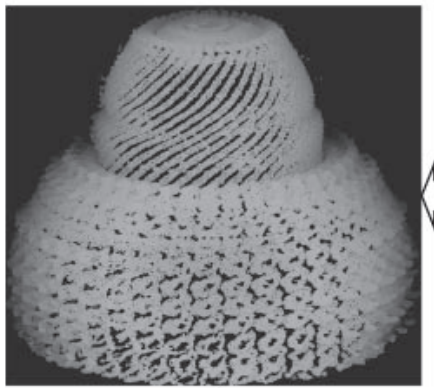

$4 \AA$
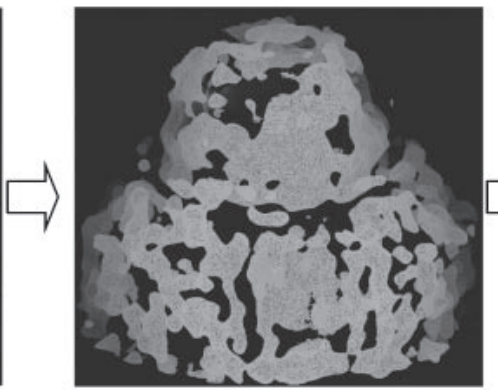

$20 \AA$

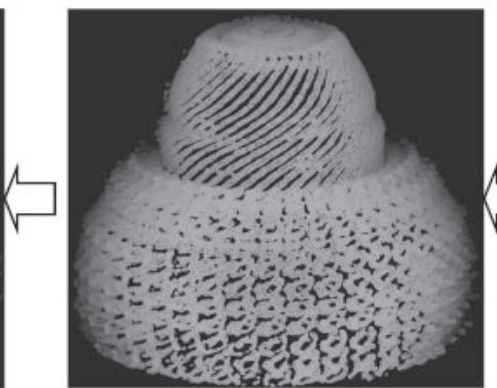

$6 \AA$

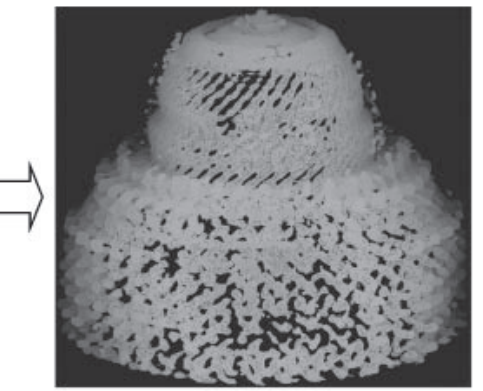

$10 \AA$

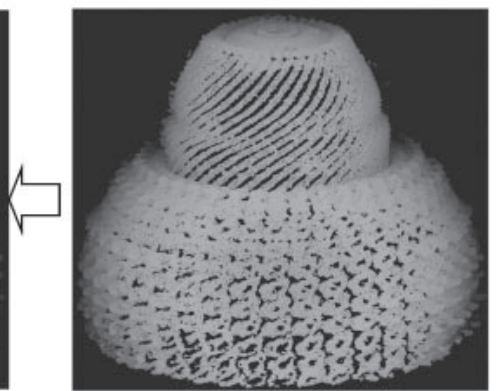

$8 \AA$

Fig. 6. Improvements in electron density during phase extension procedure from $30 \AA$ to $4 \AA$ resolution. Phase extension was performed using NCS averaging based on the 3-fold rotational symmetry. Phase extension was started at $30 \AA$ resolution. The averaged electron density map became clearer as the resolution became higher. The electron density map at $4 \AA$ resolution shows a long helix in the cap domain and repeat structures the body domain. 

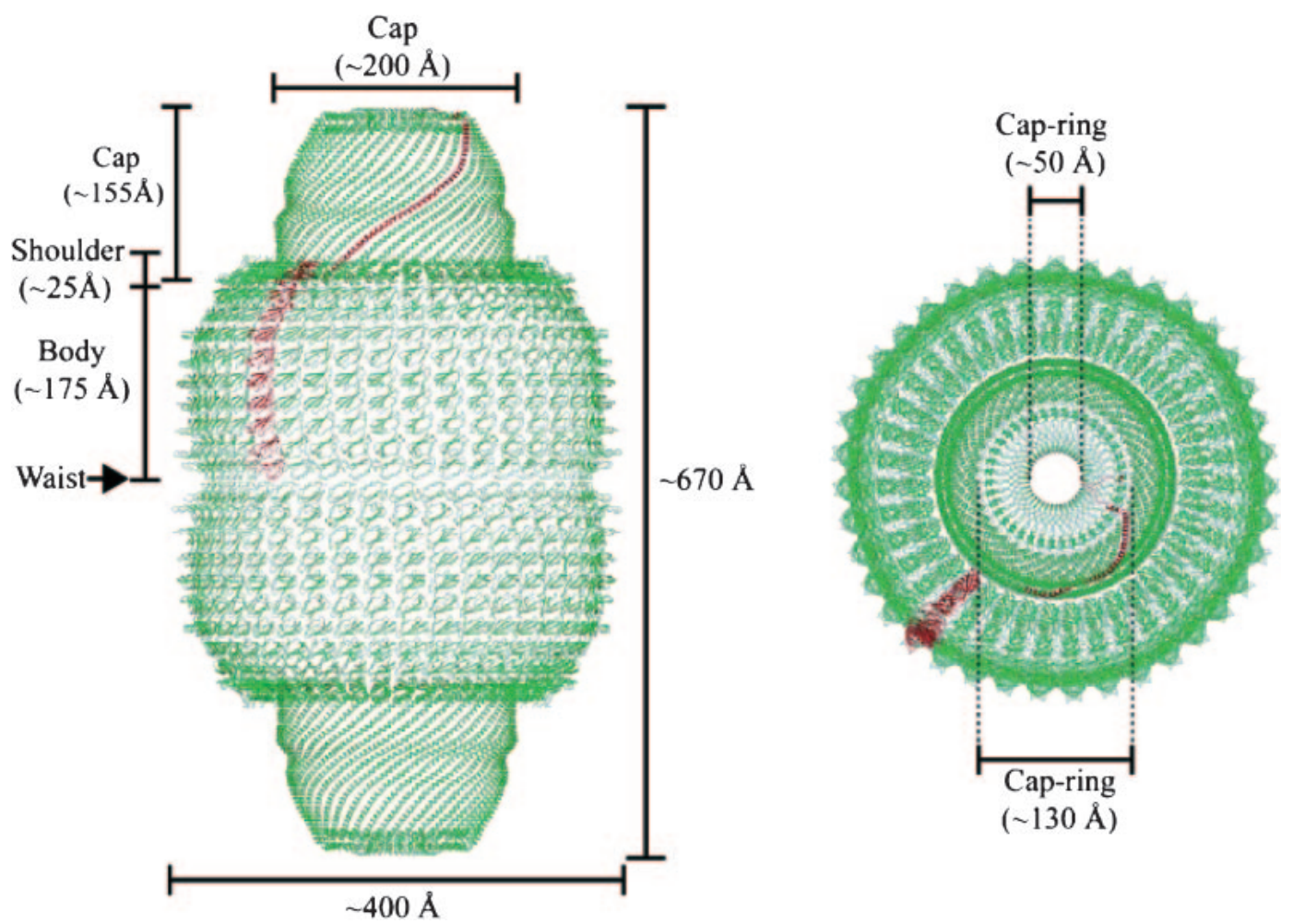

Fig. 7. Overall structure of the vault shell based on a ribbon representation of the $\mathrm{C} \alpha$ trace. One MVP molecule is shown in maroon, and the others are shown in green. Left panel, Side view of a vault shell comprising a 78-oligomer polymer of MVP molecules. The particle is $\sim 670 \AA$ from the top to the bottom, with a maximum diameter of $\sim 400 \AA$. The particle has two protruding caps, two shoulders, and a body with an invaginated waist. Two half-vault particles associate at the waist via the N-terminal domains of MVP. Right panel, Top view of the ribbon representation. The maximum diameter of the cap is $\sim 200 \AA$. The outer and inner diameters of the cap-ring domain are shown.

function indicated that the particle belonged to a $D_{\mathrm{n}}$ point group, although the rotation number was not well defined. To determine the rotational symmetry at $(\varphi, \psi)=\left(110^{\circ}, 90^{\circ}\right)$, phase refinements were performed using noncrystallographic symmetry (NCS) averaging with program $\mathrm{DM}^{34)}$ by assuming 2 - to 48-fold rotational symmetries. Initial phases were calculated at $30 \AA$ resolution using the electron microscopy model and phases were extended to $10 \AA$ resolution. $R$ factors and correlation coefficients between observed and calculated structure factors obtained from each round of NCS averaging are plotted in Fig. 5. At 3-fold, 13-fold and 39-fold symmetries, $R$ factors were significantly smaller than neighboring symmetries and correlation coefficients exhibited significantly higher peaks. $R$ values and correlation coefficients indicated that vault particles exhibit 3-, 13- and 39-fold symmetry. Consequently, vault belongs to the $D_{39}$ point group. ${ }^{31}$

The structure of the form VIa crystal was determined up to $3.5 \AA$ resolution using NCS averaging. After 3,560 cycles of 3-fold NCS averaging and phase extension cycles, the $R$ factor and the correlation coefficient converged to 0.137 and 0.971 , respectively. The improvement in electron density distribution based on the NCS averaging procedure is shown in Fig. 6. The $3.5 \AA$ resolution map showed that vault contains $78 \mathrm{MVP}$ chains with 39 -fold dihedral symmetry owing to the 39 MVP chains in each half-vault particle (Fig. 7). ${ }^{4)}$ Of the 861 aminoacid residues in MVP, we determined the tertiary structures, including side-chain orientations, of 782 residues from Met1 to Pro815. Leu429 to Pro448, Met608 to Pro620 and Phe846 to Lys861 were not included in the structure, and only the $\mathrm{C} \alpha$ trace was identified for Glu816 to Ala845. Thus, the shell structure consisting of 78 MVP molecules was successfully determined.

High resolution analyses were performed for the N-terminal fragment of MVP (amino-acid residues Met1 to Asp383) containing the first seven structural repeats $(\mathrm{R} 1-\mathrm{R} 7) .{ }^{32)}$ The structure of the monoclinic 


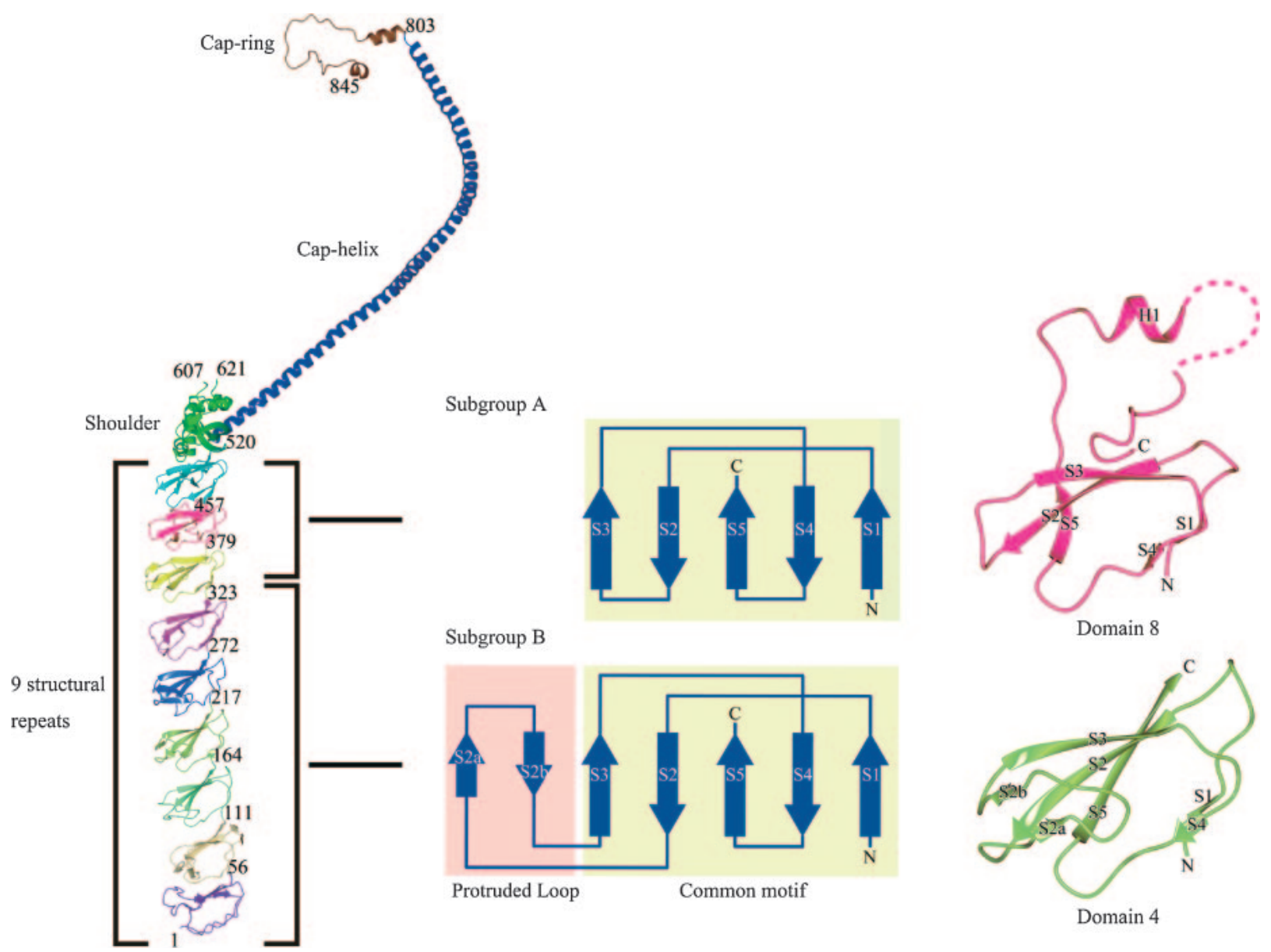

Fig. 8. Left panel, Ribbon representation of an MVP monomer. An MVP monomer contains nine structural repeat domains (R1 to R9), a shoulder domain, a cap-helix domain and a cap-ring domain. N-terminal residue of each domain is represented by numbering along the amino acid sequence. Each domain is depicted in a different color: domain 1 (Met1-Pro55), domain 2 (Arg56-Thr110), domain 3 (Pro111-Ile163), domain 4 (Gln164-Val216), tan; domain 5 (Asp217-Val271), domain 6 (Pro272-Asp322), domain 7 (Val323-Gln378), domain 8 (Ala379-Arg456), domain 9 (Val457-Gly519), shoulder domain (Pro520-Val646), cap-helix domain (Asp647-Leu802) and cap-ring domain (Gly803-Ala845). Middle panels, Two $\beta$-sheet topology diagrams of the structural repeat domains. Subgroup A consists of five antiparallel $\beta$ strands (S1 to S5), whereas subgroup B has additional strands (S2a and S2b) between S2 and S3. The R1 to R7 structure repeat domains belong to subgroup B, whereas R8 and R9 belong to subgroup A. Right panels, Ribbon drawings of R8 (top) and R4 (bottom).

form XI crystal $(2.5 \AA$ resolution) was determined using multiwavelength anomalous dispersion of seleniomethionated protein. Structures of the form IX crystal ( $2.1 \AA$ resolution) and form X crystal $(3.0 \AA$ resolution $)$ were solved using molecular replacement and the coordinates of the form XI crystals as an initial model.

A density modification procedure with program $\mathrm{DM}^{34)}$ was used to examine form VIc crystals $(8.0 \AA$ resolution) with the two R1-R7 rings as starting phases and 39-fold rotational symmetry. The final averaged map was refined to $8 \AA$ resolution. Secondary structure elements were detected and annotated using the program SSEHunter, ${ }^{35)}$ resulting in the same overall structure as that described for the $\mathrm{C} 2$ crystal (form VIa) determined at $3.5 \AA$ resolution. ${ }^{4)}$

\section{Structure of vault}

Capsid structure consisting of MVP. The vault shell measures $\sim 670 \AA$ in length with a maximum diameter of $\sim 400 \AA$ (Fig. 7). The barrel wall is only $15-25 \AA$ thick and encloses an internal cavity with the length of $\sim 620 \AA$ and a maximum diameter of $\sim 350 \AA$, large enough to enclose most objects in cells. Half-vault particles consist of a body, a shoulder and a cap. The body contains 78 copies of 

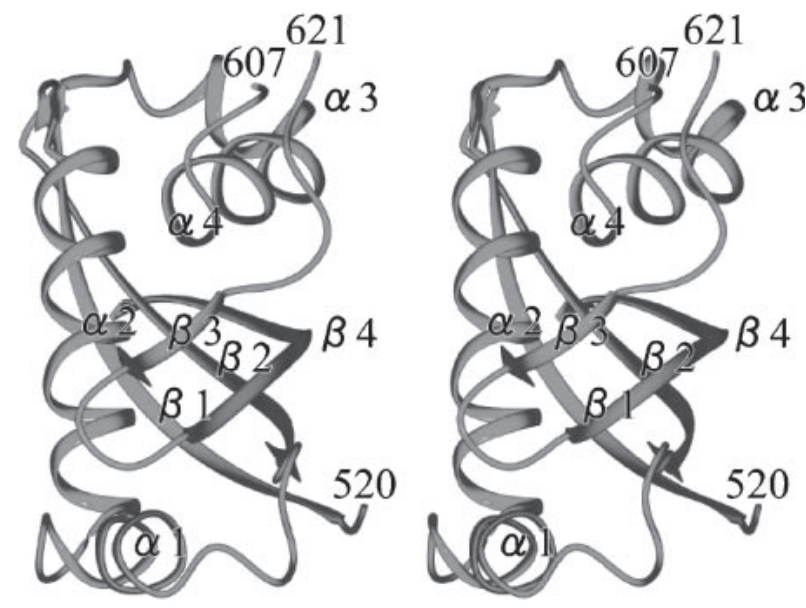

Fig. 9. A stereoscopic pair of the shoulder domain (Pro520Val646). From the N-terminal end to the C-terminal end, the secondary structure elements are $\beta 1, \beta 2, \alpha 1, \alpha 2, \alpha 3, \alpha 4, \beta 3$ and $\beta 4$. A structural model of residues $608-620$ has not been built

the nine MVP structural repeat domains (39 copies in each half-vault particle), with the waist formed by end-to-end associations of the R1 structural repeat domain. The height of the shoulder region is $\sim 25 \AA$ along the 39-fold axis, and the diameter is $\sim 315 \AA$. Caps are located at both ends of vault, each consisting of 39 copies of the cap-helix domain (Asp647 to Leu802) and cap-ring domain (Gly803 to Ala845). The height of the cap is $\sim 155 \AA$ and the inner and outer diameters of the cap-ring domain are $\sim 50 \AA$ and $\sim 130 \AA$, respectively (Fig. 7).
Structure of MVP. The nine structural repeat domains (R1-R9) can be classified into two subgroups based on the topologic arrangements of the antiparallel $\beta$ strands. Structural repeat domains R8 and R9 consist of five antiparallel $\beta$ strands termed S1, S2, S3, S4 and S5 (Fig. 8). The other seven structural repeats have two additional antiparallel $\beta$ strands (S2a and S2b) inserted between S2 and S3 (Fig. 8). The latter structure is consistent with the domain structures of R3 and R4 that were determined by the solution NMR method. ${ }^{23)}$ The structures of the R3 to R7 structural repeat domains determined at $2.1 \AA$ resolution were consistent with those determined at $3.5 \AA$ resolution, whereas there were some differences for the R1 and R2 structural domains. The higher resolution analysis indicated that the $\mathrm{R} 1$ structural repeat domain consists of five antiparallel $\beta$ strands like the R8 and R9 structural repeat domains, and the $\mathrm{R} 2$ structural repeat domain has two longer antiparallel $\beta$ strands inserted between S2 and S3. Each structural repeat domain has a hydrophobic core as observed for the R3 domain (Leu121, Leu123, Trp143, Phe145, Pro148, Tyr151, Val159 and Ile162) and R4 (Leu174, Leu176, Trp196, Val198, Leu205, Ala207, Val212 and Leu215), which was first identified in a solution NMR structural study. ${ }^{23)}$ Sequence analyses predicted two possible EF hand domains in R3 and R4 structural repeats. ${ }^{35)}$ Further studies showed that MVP interacted with other proteins, such as PTEN, via the proposed $\mathrm{EF}$ hands with $\mathrm{Ca}^{2+}$ modulating the
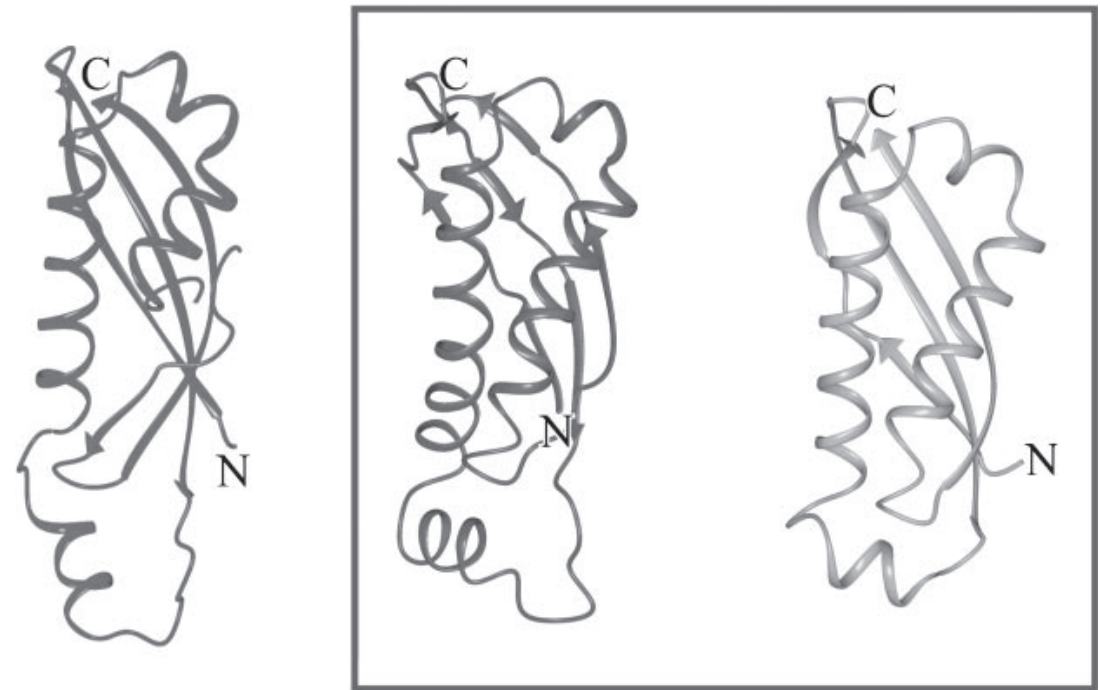

Fig. 10. Ribbon representations of the shoulder domain (left) and SFPH domains from $\mathrm{PhSto}^{\mathrm{CD}}$ (middle) and Flot ${ }^{\mathrm{BD} 7}$ (right). Although the sequence of the shoulder domain is not particularly homologous with that of the $\mathrm{SPFH}$ domain from $\mathrm{PhSto}{ }^{\mathrm{CD}}(10.2 \%$ identity) or Flot $^{\mathrm{BD} 7}$ (6.3\% identity), the tertiary structures of the domains are very similar. 

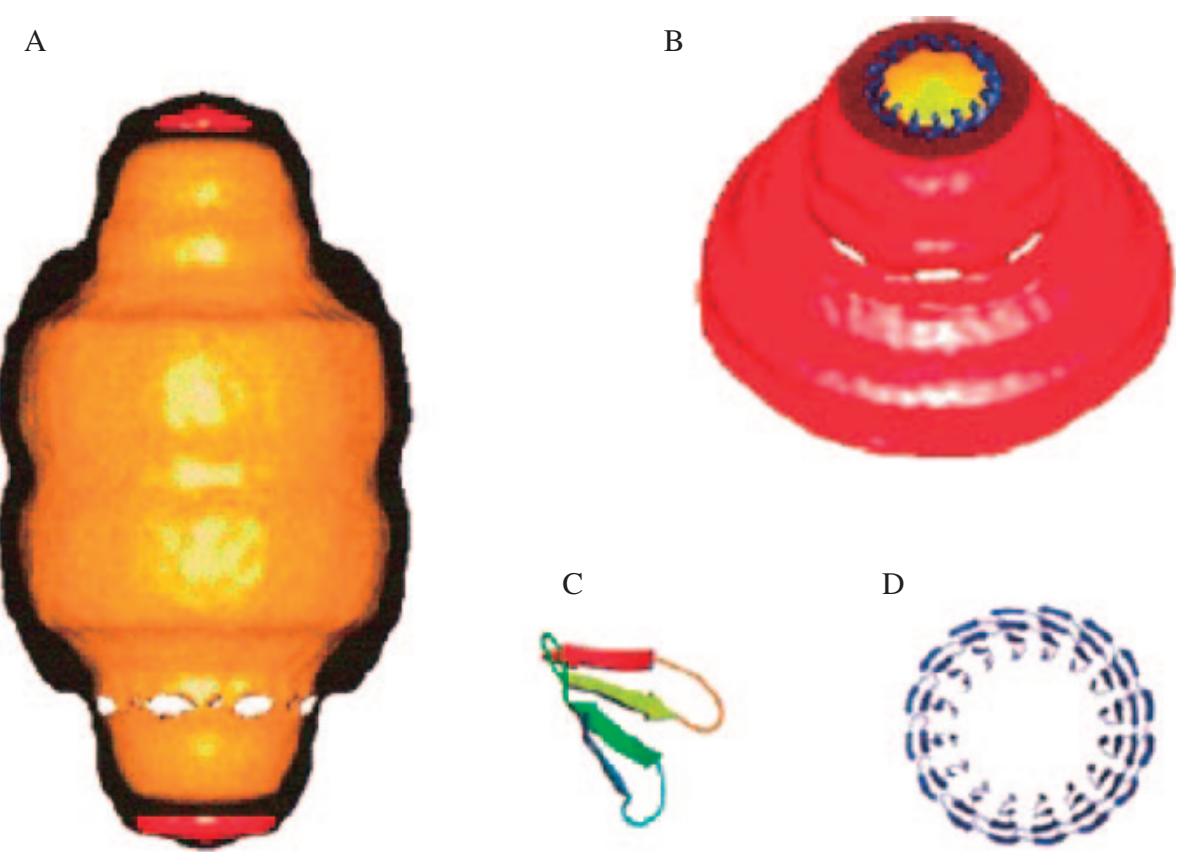

Fig. 11. Location of TEP1 and vRNA. (A) vRNA (red) is located at the ends of the vault caps based on the different density maps for RNase-treated and intact vault reconstructions. (B) Colocalization of TEP1 and vRNA. Vault (red) is shown with the TEP1 WD40 domain (blue) and vRNA (yellow). (C) Modeling of the TEP1 WD40 repeat domain using a portion of the structure of the heterotrimeric G-protein $\beta$ subunit. (D) A circular $\beta$-propeller model of the TEP1 WD40 repeat. Figures are reproduced from Kong et al. ${ }^{9)}$ with copyright permission from the RNA Society.

interactions. $^{21), 36)}$ The reported structures, however, all have $\beta$-sheet conformations without EF hand domains or calcium-binding cavities. Moreover, neither $\mathrm{Ca}^{2+}$ nor any other ion has been detected in the reported structures.

The shoulder domain (Pro520 to Val646) folds into a single $\alpha / \beta$ globular domain with a fourstranded antiparallel $\beta$ sheet on one side and four $\alpha$ helices on the other side (Fig. 9). A search for threedimensional structures similar to the shoulder domain using the DALI server ${ }^{37}$ ) identified the core domain of stomatin from Pyrococcus horikoshii $\left(\mathrm{PhSto}^{\mathrm{CD}}\right)(\mathrm{PDB} 3 \mathrm{BK} 6)^{38)}$ and the flotillin-2 band-7 domain (Flot ${ }^{\mathrm{BD} 7}$ ) (PDB 1WIN) (Fig. 10). The structure of the shoulder domain has been superimposed on those of $\mathrm{PhSto}^{\mathrm{CD}}$ and Flot ${ }^{\mathrm{BD} 7}$, resulting in root-mean-square deviation values of $2.1 \AA$ and $2.2 \AA$, respectively. The core domain of stomatin is evolutionarily conserved and part of the stomatin-prohibitin-flotillin-HflK-C (SPFH) domain family. ${ }^{39), 40)}$ Although the physiological function of stomatin is not clearly understood, the SPFH domain is known to be involved in binding to lipid rafts. ${ }^{40)}$ Human stomatin, which shares $40.3 \%$ and $18.4 \%$ sequence identities with $\mathrm{PhSto}^{\mathrm{CD}}$ and Flot ${ }^{\mathrm{BD}}$, respectively, is an integral membrane protein in erythrocytes. Podocin from mouse and mechanosensory protein 2 from Caenorhabditis elegans have SPFH domains that bind cholesterol, which likely contribute to the association of these proteins to lipid rafts. ${ }^{41)}$ The structural similarities between the shoulder domain and SPFH domain family supports an interaction between MVP and lipid rafts-for example, when human lung epithelial cells are infected with Pseudomonas aeruginosa. ${ }^{28)}$

The cap-helix domain forms a 42-turn $\alpha$ helix that exhibits a superhelical structure with a quarter turn, and the cap-ring domain at the end of the cap forms a U-shaped structure with helical elements at both ends (Fig. 7).

Locations of TEP1, vRNA and VPARP in the capsid. Cryoelectron microscopic structures of untreated and RNase-treated rat vault were reconstructed at $22 \AA$ resolution. ${ }^{9)}$ Difference imaging between untreated and RNase-treated vault indicated that vRNA is located in the caps at the ends of the vault particles (Fig. 11). Cryoelectron microscopic difference maps were analyzed to determine the locations of TEP1. ${ }^{2)}$ Some TEP1 difference maps showed electron densities in the top flat portion of the vault cap, an area that was previously shown to contain a circular $\beta$-propeller structure of the TEP1 

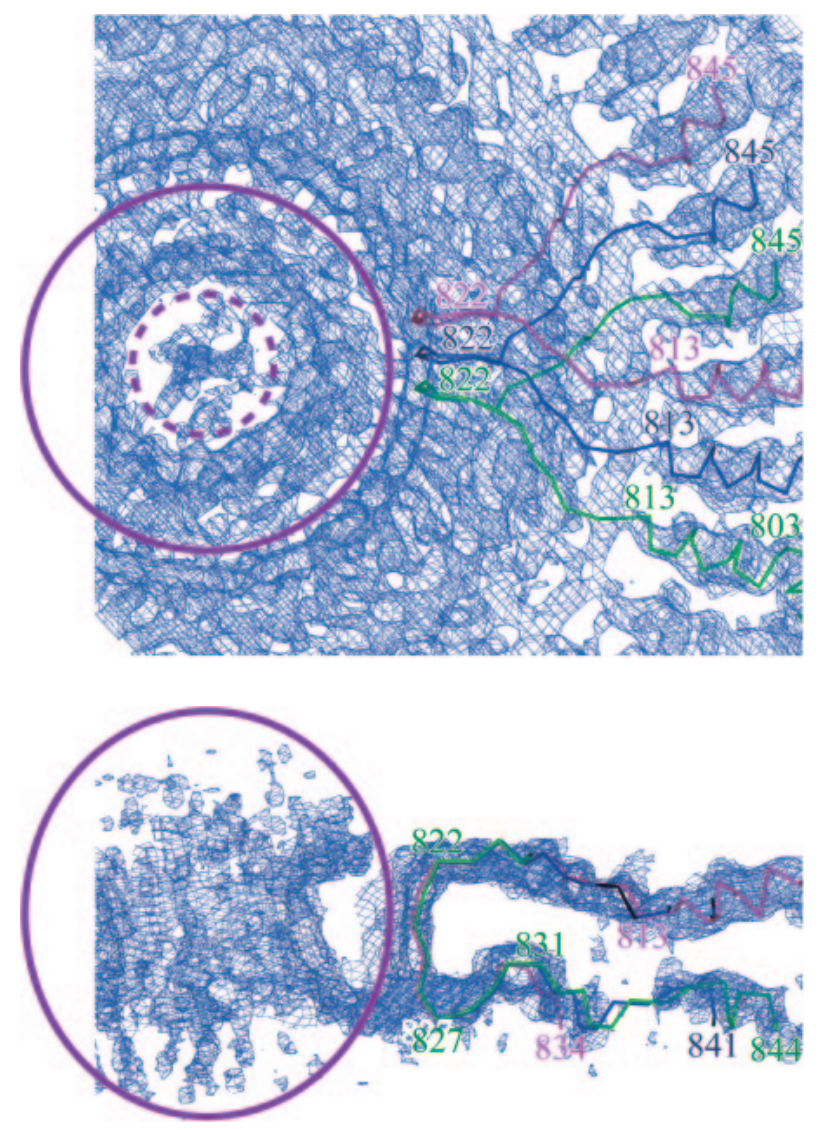

Fig. 12. An electron density map of the cap-ring domain (residues 803-845) shown at $2.0 \sigma$. The residue numbers of each molecule are shown in same color as the chain. Top panel, A top view of the map. Bottom panel, A side view of the map. TEP1 is likely reflected in the cylindrical electron density cage enclosed between the purple circle and dashed purple circle in the top panel, and the electron dense area in the purple ellipse in the bottom panel. The cylindrical structure has an outer diameter of $\sim 45 \AA$, an inner diameter of $\sim 20 \AA$ and a height of $\sim 30 \AA$. vRNA, which interacts with TEP1, ${ }^{13), 14)}$ may be represented by the region enclosed in the red dashed circle in the top panel.

WD40 repeat. ${ }^{9)}$ Another weakly electron dense area that may reflect TEP1 was detected in the internal cavity of the cap. ${ }^{2}$ The N-terminal half of TEP1 contains four repeats of unknown function, an RNAbinding domain with three regions homologous to the Tetrahymena p80 protein, and an ATP/GTPbinding motif. ${ }^{13), 14)}$ Using a yeast three-hybrid assay, TEP1 was shown to interact with telomerase RNA and various human vRNAs. ${ }^{14), 42), 43)}$

A bulky electron dense area at the top of the ring remains unassigned in the $3.5 \AA$ map; because the area is barrel-shaped with an outer diameter of $\sim 45 \AA$, an inner diameter of $\sim 20 \AA$, and a height of $\sim 30 \AA$ (Fig. 12), it may represent the circular TEP1
Table 3. Inter subunit interactions

\begin{tabular}{lcccc}
\hline & $\begin{array}{l}\text { Hydrogen } \\
\text { bond } \\
(\sim 3.2 \AA)\end{array}$ & $\begin{array}{l}\text { Ionic pair } \\
(\sim 4.5 \AA)\end{array}$ & $\begin{array}{l}\text { Hydrophobic } \\
\text { interaction } \\
(\sim 4.5 \AA)\end{array}$ & $\begin{array}{l}\text { Interaction/ } \\
\text { amino acid } \\
(\%)\end{array}$ \\
\hline $\begin{array}{l}\text { Overall } \\
(1-804)\end{array}$ & 26 & 9 & 39 & 9.2 \\
$\begin{array}{l}\text { Cap domain } \\
(646-804)\end{array}$ & 10 & 5 & 29 & 25.9 \\
$\begin{array}{l}\text { Shoulder } \\
\text { domain }\end{array}$ & & & & \\
$\begin{array}{l}(519-645) \\
\text { nine repeat }\end{array}$ & 6 & 2 & & \\
$\begin{array}{l}\text { domains } \\
(1-518)\end{array}$ & 10 & & & \\
\hline
\end{tabular}

protein (Fig. 11). ${ }^{9)}$ The electron dense location inside the barrel-shaped area of TEP1 in the $3.5 \AA$ map (Fig. 12) may reflect vRNA located in the top of the cap ring as shown in Fig. 11.9)

Coexpression of MVP with VPARP and/or TEP1 resulted in assembly of regularly shaped vaults. To localize VPARP in vault, difference maps between a number of combinations of cryoelectron microscopic reconstructions were analyzed. ${ }^{2)}$ All of the difference maps revealed a strongly dense band on the inner surface of the vault barrel (Fig. 13(A), lower arrowhead and (C) lower arrow), which is inside the R4 structural repeat domain. A thinner VPARP-derived band was detected in the inner surface of the vault cap (Fig. 13(A), upper arrowhead and (C) upper arrow), which is near Glu717 in the cap-helix domain (Asp647 to Leu802). A third weak VPARP-derived band was identified at the inner surface of the R9 structural repeat domain (Fig. 13(B), arrow and (C) middle arrow).

Intermolecular interactions in vault particles. In the cap-helix domain, most polar residues are exposed at the inner or outer surfaces of the particle, whereas hydrophobic residues interact at the interface between two helices (Fig. 14). Specific ionic pairs in the cap-helix domain are noted in Fig. 15. The number of interactions is listed in Table 3. Of the 74 total interactions between adjacent MVP subunits, 44 were between cap domains and 20 intermolecular interactions were detected among the nine structural repeats in the body. The interactions between cap domains pro- 

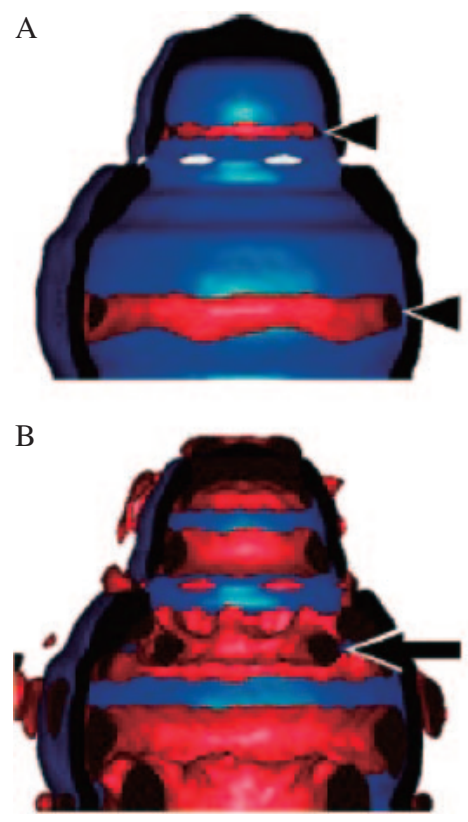

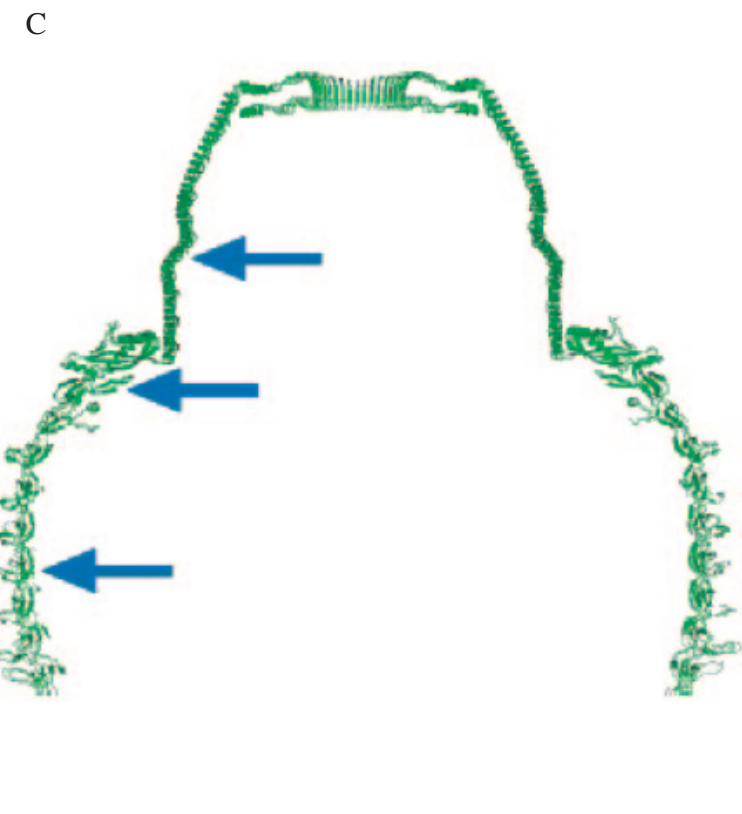

Fig. 13. VPARP is located in the top half of the vault based on cryoelectron microscopic imaging of recombinant vault particles. (A) A cryoelectron microscopic difference map of VPARP — vault with recombinant HisT7-MVP/VPARP/TEP1 minus vault with recombinant vsvg-MVP/TEP1 - is shown in red with the isosurface value set above the level of background noise. (B) The same VPARP difference map shown with the isosurface value set to include weak differences in density and some noise. The three density bands assigned to VPARP are indicated with arrows in (A) and (B). The difference density map is superimposed on the reconstruction of vault with recombinant vsvg-MVP/TEP1 (blue). Figures (A) and (B) are reproduced from Mikyas et al. ${ }^{2}$ ) with copyright permission from Elsevier. (C) A vertically sliced section of a ribbon representation with three VPARP sites (arrows). The major site denoted by the lower arrow is inside the R4 structural repeat domain. A minor VPARP site marked with the upper arrow is near Glu717 in the cap-helix domain. A third site denoted by the middle arrow is at the inner surface of the R9 structural repeat domain.

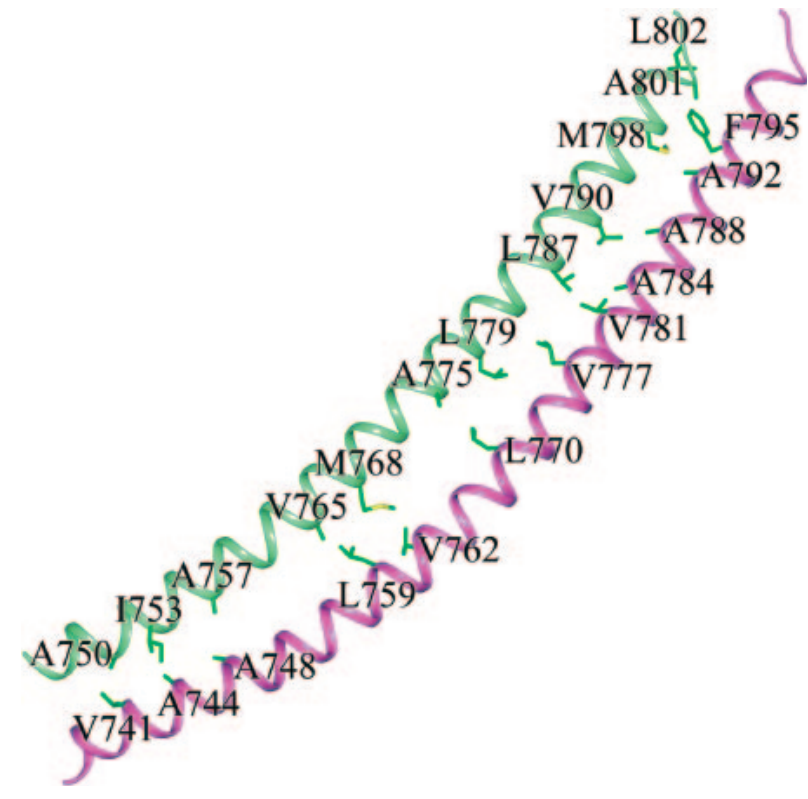

Fig. 14. Hydrophobic interactions between two adjacent caphelix domains. The two helices are depicted with ribbon representations and different colors. Amino-acid residues that interact with those from the adjacent helix are identified with single letters and residue numbers. mote self-assembly of half-vault particles. A yeast two-hybrid system demonstrated the interactions between MVPs via their cap-helix domains, too. ${ }^{36)}$ Only $3.9 \%$ of amino acids in the nine structural repeat domains contribute to intersubunit interactions, compared with $25.9 \%$ of amino-acid residues in the cap domain that interact with adjacent subunits. Thus, side-by-side interactions in the body are weaker than the interactions stabilizing the cap structure. Electron microscopy of half-vault particles showed that MVP structural repeat domains appear as petals around the central ring formed by the cap structure. $^{10)}$

$\mathrm{N}$-terminal residues of the $\mathrm{R} 1$ structural repeat domain in MVP (Met1-Glu4) form an intermolecular antiparallel $\beta$ structure with the molecule related by two-fold axis symmetry (Fig. 16). ${ }^{4)}$ An ionic bond between Glu4 and Arg42 also forms between two half-vault particles. In contrast to the association of C-terminal cap domains, $\mathrm{N}$-terminal associations are characterized by numerous hydrophilic interactions. Querol-Audi et al. ${ }^{32)}$ positioned the structure of the R1-R7 domains at $2.1 \AA$ resolution onto the $8 \AA$ map 


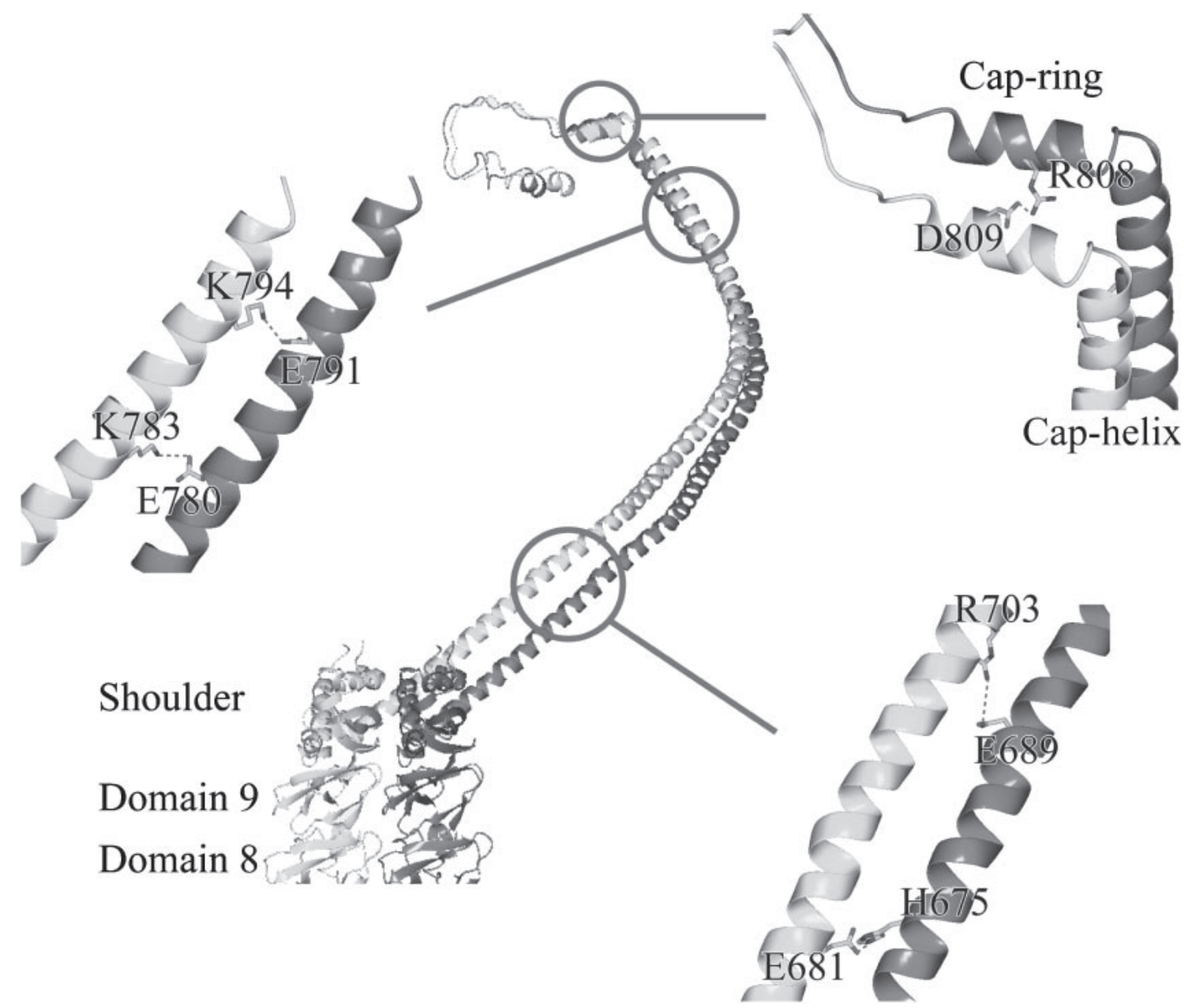

Fig. 15. Five ionic interactions between adjacent subunits. Middle panel, Two subunits are shown from the R8 structural repeat domain to the cap-ring domain using ribbon representations. Left panel, Salt bridges between Glu780 and Lys783, and Glu791 and Lys794 in C-terminal regions of the cap-helix domains. Top right panel, A salt bridge between Arg808 and Asp809 in the N-terminal helices of the cap-ring domains. Bottom right panel, Ionic interactions between His675 and Glu681, and Glu689 and Arg703 in N-terminal regions of the cap-helix domains. Amino acids are identified with single letters and residue numbers.

of the form VIc crystal and the $3.5 \AA$ map of the form VIa crystal, revealing important complementary charges at the interface between the two vault halves. This approach suggested that side chain of Asp39 forms a salt bridge with Arg42 and contacts the main chain $\mathrm{N}$ atoms of Ala21 and Gln22, which is different from the analysis of Tanaka et al. of the $3.5 \AA$ structure. $\left.{ }^{4}\right)$ Charged Glu4, Glu5 and Arg37 and hydrophobic Ala6, Ile7 and Ile36 also interact at the contact surface through the two-fold symmetry axis. Vault dissociates into the two halves at low $\mathrm{pH}$, owing to neutralization of the acidic residues at the interface and the resulting overall electropositive charge (Fig. 17). ${ }^{44), 45)}$ At higher $\mathrm{pH}$, the electrostatic interactions are reestablished, allowing reassociation of the two vault halves. Of note, in the crystals of the R1-R7 domains obtained at $\mathrm{pH} 5.6$, Asp39 was protonated and located close to the peptide oxygen of Gly354 from the R7 repeat domain of a neighboring subunit. ${ }^{32)}$

\section{Discussion}

Structural studies of vault particles have been performed using x-ray diffraction, ${ }^{4), 22), 30), 32)}$ electron microscopic, ${ }^{1,2), 9), 10,29)}$ and $\mathrm{NMR}^{23)}$ methods. X-ray crystallographic analyses ${ }^{4), 31), 32)}$ indicate that vault particles from rat liver exhibit 39-fold symmetry. Although the 48-fold symmetry that was proposed based on various electron microscopic images ${ }^{10), 29)}$ has not been confirmed using high-resolution x-ray 


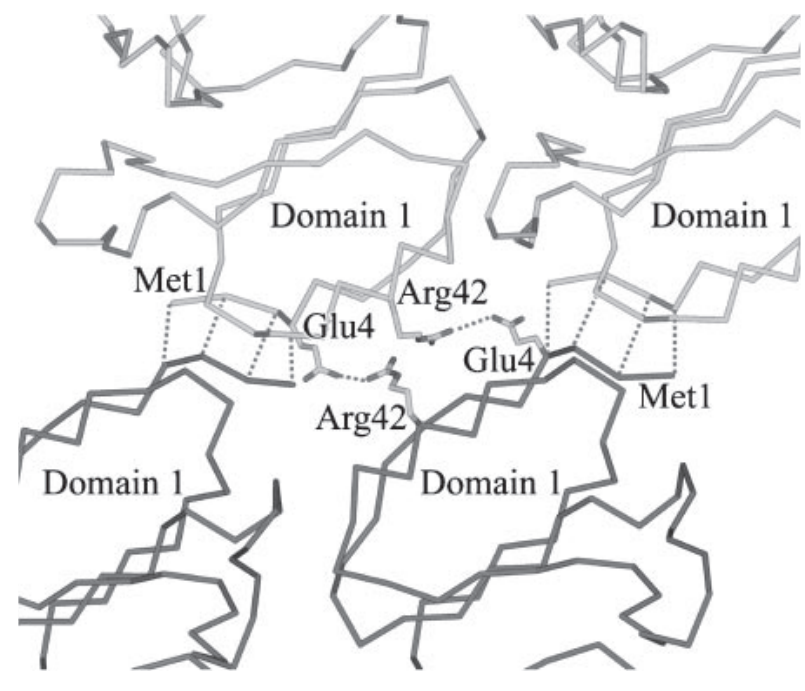

Fig. 16. Intermolecular interactions between two half-vault particles. N-terminal residues of the $\mathrm{R} 1$ structural repeat domain (Met1-Glu4) form an intermolecular antiparallel $\beta$ sheet with the same residues from the molecule exhibiting two-fold symmetry. Other specific interactions between the two half-vault particles include an ionic bond between Glu4 and Arg42. In contrast to the association between C-terminal cap domains, many Nterminal associations are hydrophilic.

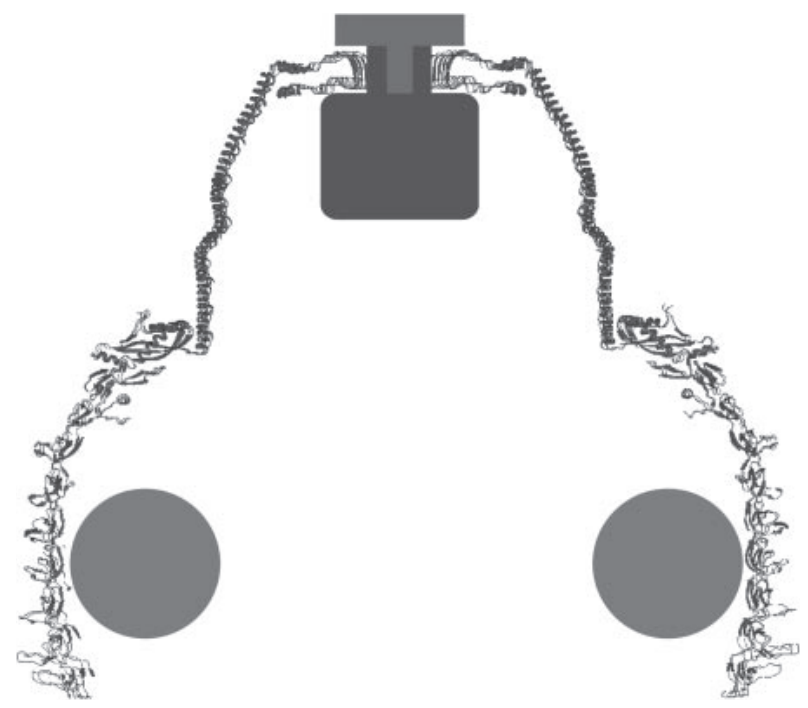

Fig. 18. A vertically sliced section of a half vault structure. The capsid structure consisting of MVP molecules is shown in a ribbon representation. Gray circles denote VPARP molecules on the inside of the $\mathrm{R} 4$ repeat domain; the molecules are spherical with a diameter of $94 \AA$. TEP1 in the cap region of vault consists of a $100 \times 100 \times 80 \AA^{3}$ circular column and a $45 \times 45 \times 30 \AA^{3}$ cylinder (black). The vRNA molecule at the end of the cap region consists of a $15 \times 15 \times 30 \AA^{3}$ circular column and an $82 \times 82 \times 20 \AA^{3}$ circular disc (gray).
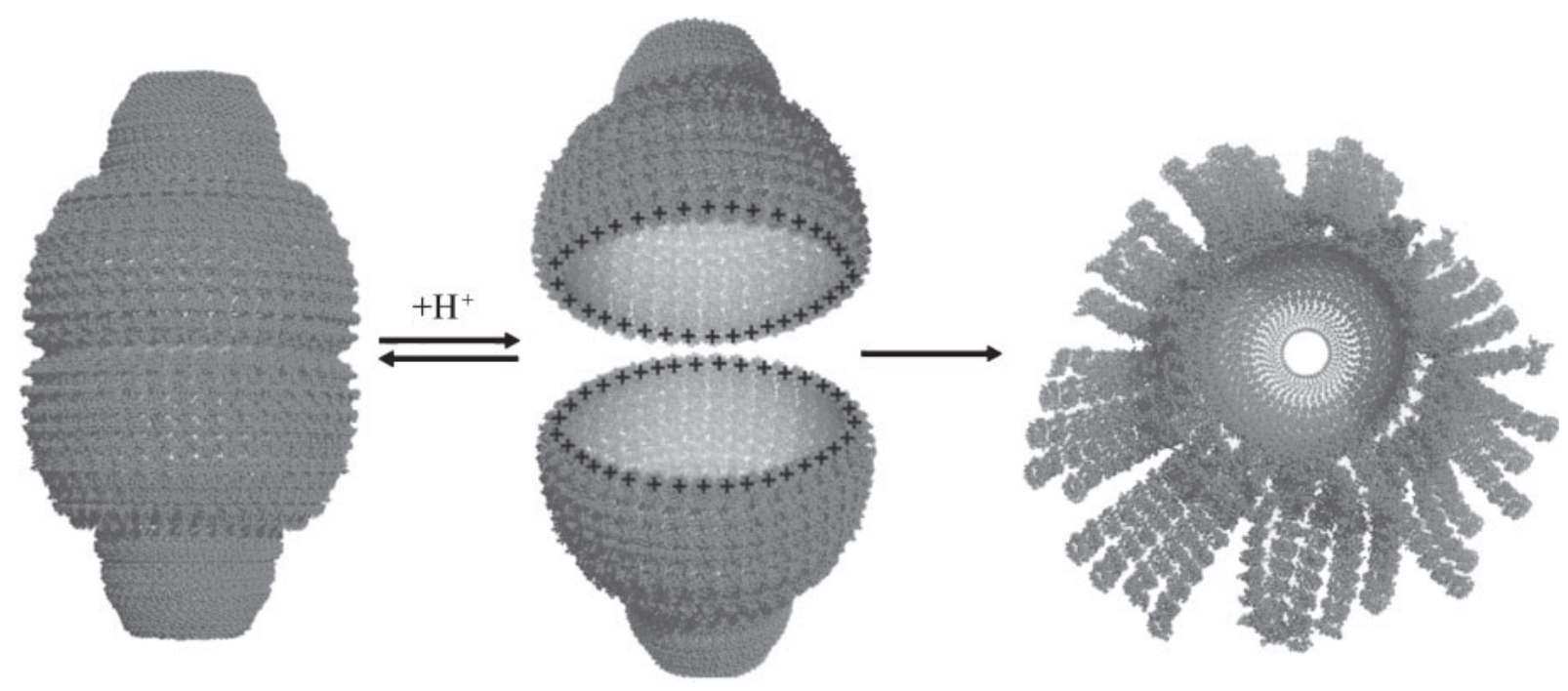

Fig. 17. A schematic representation of the opening of vault particles. At low pH, acidic residues at the vault interface are neutral, resulting in an electropositive area, reduced ionic attractive force, and disassembly of the vault particle owing to charge repulsion. The half vault moiety on the right of the figure corresponds to the flower-like structures described by Kedersha et al. ${ }^{10)}$ Figures are reproduced from Querol-Audí et al. ${ }^{22)}$ with copyright permission from the Nature Publishing Group.

analysis, this structure may be present in a specific condition. Fig. 18 includes a model of the locations of TEP1, VPARP and vRNA in the MVP capsid based on electron microscopic analyses. ${ }^{2,9)}$ The major site of VPARP based on electron microscopic difference mapping is close to the R4 structural repeat domain. $\left.{ }^{2}\right)$ The specific volume of the protein molecule is approximately $0.74 \mathrm{~cm}^{3} / \mathrm{g}$. Assuming 
VPARP is a spherical particle with a molecular weight of $\sim 192 \mathrm{kDa}$, its estimated diameter is $\sim 94 \AA$. TEP1 with a molecular weight of $\sim 291 \mathrm{kDa}$ consists of a cylindrical region (inner diameter, $20 \AA$; outer diameter, $45 \AA$; height, $30 \AA$ ) and a circular column $\left(100 \times 100 \times 80 \AA^{3}\right)$. The cylindrical region corresponds to the barrel structure of TEP1 shown in Fig. 11B. vRNA is located at the ends of the vault caps (Fig. 11A) and may interact with both the interior and exterior environments. ${ }^{9)}$ Further, a $\sim 49$-KDa vRNA molecule is located next to TEP1 (Fig. 18). Some vRNA is present in a column $\left(15 \times 15 \times 30 \AA^{3}\right)$ in the cylindrical structure of TEP1, and some is in a disk $\left(82 \times 82 \times 20 \AA^{3}\right)$ at the end the cap. Because the total amount of vRNA in a vault particle is $\sim 460 \mathrm{kDa}$, which is equivalent to $4.6 \%$ of the total weight of the particle, only vRNA molecules are located in other places in the cell. The locations of the remaining vRNA transcripts are not known.

The occasional occurrence of a mass in the inner hollow cavity led to the hypothesis that the vaults might function as transport vehicles. ${ }^{29)}$ The inner volume of capsular structure is calculated at $\sim 3.87 \times 10^{7} \AA^{3}$. As partial specific volume of protein is $\sim 0.74 \mathrm{~cm}^{3} / \mathrm{g}$, the vault can contain a total mass of $\sim 3.14 \times 10$ Da proteins within its capsid. Dissociation of the vault into two half vaults at low $\mathrm{pH}$ is caused by weakened ionic interaction between N-terminal R1 domains of two opposing halfvaults. ${ }^{32), 44)}$ Many inter-subunit interactions detected in the cap domain stabilize the half-vault structure. ${ }^{4)}$ The dissociation into two half-vaults is an important step for the vault to capture substances. These structural evidences suggest that vaults are likely to transport various substances in the cell.

\section{Acknowledgements}

This work was supported in part by grants-inaid for scientific research (21227003) (to T.T.), and Grant-in-Aid for Young Scientists (A) (24687020) (to H.T.) and Grant-in-Aid for Scientific Research on Innovative Areas (23121517) (to H.T.) from the Ministry of Education, Culture, Sports, Sciences and Technology of Japan, and PRESTO program grant from Japan Science and Technology Agency (to H.T.).

\section{References}

1) Kedersha, N.L. and Rome, L.H. (1986) Isolation and characterization of a novel ribonucleoprotein particle: large structures contain a single species of small RNA. J. Cell Biol. 103, 699-709.

2) Mikyas, Y., Makabi, M., Raval-Fernandes, S., Harrington, L., Kickhoefer, V.A., Rome, L.H. and Stewart, P.L. (2004) Cryoelectron microscopy imaging of recombinant and tissue derived vaults: Localization of the MVP N termini and VPARP. J. Mol. Biol. 344, 91-105.

3) Kedersha, N.L., Miquel, M.C., Bittner, D. and Rome, L.H. (1990) Vaults. II. Ribonucleoprotein structures are highly conserved among higher and lower eukaryotes. J. Cell Biol. 110, 895-901.

4) Tanaka, H., Kato, K., Yamashita, E., Sumizawa, T., Zhou, Y., Yao, M., Iwasaki, K., Yoshimura, M. and Tsukihara, T. (2009) The structure of rat liver vault at 3.5 angstrom resolution. Science $\mathbf{3 2 3}$, $384-388$.

5) Kickhoefer, V.A., Siva, A.C., Kedersha, N.L., Inman, E.M., Ruland, C., Streuli, M. and Rome, L.H. (1999) The $193-\mathrm{kD}$ vault protein, VPARP, is a novel poly(ADP-ribose) polymerase. J. Cell Biol. 146, 917-928.

6) Kickhoefer, V.A., Stephen, A.G., Harrington, L., Robinson, M.O. and Rome, L.H. (1999) Vaults and telomerase share a common subunit, TEP1. J. Biol. Chem. 274, 32712-32717.

7) Kickhoefer, V.A., Searles, R.P., Kedersha, N.L., Garber, M.E., Johnson, D.L. and Rome, L.H. (1993) Vault ribonucleoprotein particles from rat and bullfrog contain a related small RNA that is transcribed by RNA polymerase III. J. Biol. Chem. 268, 7868-7873.

8) van Zon, A., Mossink, M.H., Schoester, M., Scheffer, G.L., Scheper, R.J., Sonneveld, P. and Wiemer, E.A.C. (2001) Multiple human vault RNAs. Expression and association with the vault complex. J. Biol. Chem. 276, 37715-37721.

9) Kong, L.B., Siva, A.C., Kickhoefer, V.A., Rome, L.H. and Stewart, P.L. (2000) RNA location and modeling of a WD40 repeat domain within the vault. RNA 6, 890-900.

10) Kedersha, N.L., Heuser, J.E., Chugani, D.C. and Rome, L.H. (1991) Vaults. III. Vault ribonucleoprotein particles open into flower-like structures with octagonal symmetry. J. Cell Biol. 112, 225235.

11) Kickhoefer, V.A. and Rome, L.H. (1994) The sequence of a cDNA encoding the major vault protein from Rattus norvegicus. Gene 151, 257260.

12) Scheffer, G.L., Wijngaard, P.L.J., Flens, M.J., Izquierdo, M.A., Slovak, M., Meijer, C., Clevers, H.C. and Scheper, R.J. (1995) The drug resistancerelated protein LRP is the human major vault protein. Nat. Med. 1, 578-582.

13) Nakayama, J., Saito, M., Nakamura, H., Matsuura, A. and Ishikawa, F. (1997) TLP1: A gene encoding a protein component of mammalian telomerase is a novel member of WD repeats family. Cell $\mathbf{8 8}, 875$ 884 .

14) Harrington, L., McPhail, T., Mar, V., Zhou, W., Oulton, R., Bass, M.B., Arruda, I. and Robinson, M.O. (1997) A mammalian telomerase-associated 
protein. Science 275, 973-977.

15) Kickhoefer, V.A., Searlesl, R.P., Kedershall, N.L., Garber, M.E., Johnson, D.L. and Rome, L.H. (1993) Vault ribonucleoprotein particles from rat and bullfrog contain a related small RNA that is transcribed by RNA polymerase III. J. Biol. Chem. 268, 7868-7873.

16) Chugani, D.C., Rome, L.H. and Kedersha, N.L. (1993) Evidence that vault ribonucleoprotein particles localize to the nuclear pore complex. J. Cell Sci. 106, 23-29.

17) Kitazono, M., Sumizawa, T., Takebayashi, Y., Chen, Z.S., Furukawa, T., Nagayama, S., Tani, A., Takao, S., Aikou, T. and Akiyama, S. (1999) Multidrug resistance and the lung resistancerelated protein in human colon carcinoma SW620 cells. J. Natl. Cancer Inst. 91, 1647-1653.

18) Gopinath, S.C., Matsugami, A., Katahira, M. and Kumar, P.K. (2005) Human vault-associated noncoding RNAs bind to mitoxantrone, a chemotherapeutic compound. Nucleic Acids Res. 33, 4874-4881.

19) Mossink, M.H., van Zon, A., Franzel-Luiten, E. Schoester, M., Kickhoefer, V.A., Scheffer, G.L., Scheper, R.J., Sonneveld, P. and Wiemer, E.A. (2002) Disruption of major vault protein (MVP/ LRP) gene does not induce hypersensitivity to cytostatics. Cancer Res. 62, 7298-7304.

20) Huffman, K.E. and Corey, D.R. (2005) Major vault protein does not play a role in chemoresistance or drug localization in a non-small cell lung cancer cell line. Biochemistry 44, 2253-2261.

21) Yu, Z., Fatouhi-Ardakani, N., Wu, L., Maoui, M., Wang, S., Banville, D. and Shen, S.H. (2002) PTEN associates with the vault particles in HeLa cells. J. Biol. Chem. 277, 40247-40252.

22) Querol-Audí, J., Perez-Luque, R., Fita, I., LopézIglesias, C., Castón, J.R., Carrascosa, J.L. and Verdaguer, N. (2005) Preliminary analysis of two and three dimensional crystals of vault ribonucleoprotein particles. J. Struct. Biol. 151, 111-115.

23) Kozlov, G., Vavelyuk, O., Minailiuc, O., Banville, D., Gehring, K. and Ekiel, I. (2006) Solution structure of a two-repeat fragment of major vault protein. J. Mol. Biol. 356, 444-452.

24) Kolli, S., Zito, C.I., Mossink, M.H., Wiemer, E.A. and Bennett, A.M. (2004) The major vault protein is a novel substrate for the tyrosine phosphatase SHP-2 and scaffold protein in epidermal growth factor signaling. J. Biol. Chem. 279, 29374-29385.

25) Kim, E., Lee, S., Mian, M.F., Yun, S.U., Song, M., Yi, K.S., Ryu, S.H. and Suh, P.G. (2006) Crosstalk between Src and major vault protein in epidermal growth factor-dependent cell signalling. FEBS J. 273, 793-804.

26) Steiner, E., Holzmann, K., Pirker, C., Elbling, L., Micksche, M., Sutterluty, H. and Berger, W. (2006) The major vault protein is responsive to and interferes with interferon-mediated STAT1 signals. J. Cell Sci. 119, 459-469.

27) Mrázek, J., Kreutmayer, S.B., Grässer, F.A., Polacek, N. and Hüttenhofer, A. (2007) Subtrac- tive hybridization identifies novel differentially expressed ncRNA species in EBV-infected human B cells. Nucleic Acids Res. 35, e73.

28) Kowalski, M.P., Dubouix-Bourandy, A., Bajmoczi, M., Golan, D.E., Zaidi, T., Coutinho-Sledge, Y.S., Gygi, M.P., Gygi, S.P., Wiemer, E.A.C. and Pier, G.B. (2007) Host resistance to lung infection mediated by major vault protein in epithelial cells. Science 317, 130-132.

29) Kong, L.B., Siva, A.C., Rome, L.H. and Stewart, P.L. (1999) Structure of the vault, a ubiquitous cellular component. Structure 7, 371-379.

30) Anderson, D.H., Kickhoefer, V.A., Sievers, S.A., Rome, L.H. and Eisenberg, D. (2007) Draft crystal structure of the vault shell at $9 \AA$ resolution. PLoS Biol. 5, 2661-2670.

31) Kato, K., Tanaka, H., Sumizawa, T., Yoshimura, M., Yamashita, E., Iwasaki, K. and Tsukihara, T. (2008) A vault ribonucleoprotein particle exhibiting 39-fold dihedral symmetry. Acta Crystallogr. D Biol. Crystallogr. 64, 525-531.

32) Querol-Audi, J., Casanas, A., Uson, I., Luque, D., Caston, J.R., Fita, I. and Verdaguer, N. (2009) The mechanism of vault opening from the high resolution structure of the N-terminal repeats of MVP. EMBO J. 28, 3450-3457.

33) Tong, L. and Rossmann, M.G. (1997) Rotation function calculations with GLRF program. Methods Enzymol. 276, 594-611.

34) CCP4 (1994) The CCP4 suite: programs for protein crystallography. Acta Crystallogr. D Biol. Crystallogr. 50, 760-763.

35) Baker, M.L., Ju, T. and Chiu, W. (2007) Identification of secondary structure elements in intermediate-resolution density maps. Structure 15, $7-19$.

36) van Zon, A., Mossink, M.H., Schoester, M., Scheffer, G.L., Scheper, R.J., Sonneveld, P. and Wiemer, E.A. (2002) Structural domains of vault proteins: a role for the coiled coil domain in vault assembly. Biochem. Biophys. Res. Commun. 291, 535-541.

37) Holm, L. and Sander, C. (1996) Mapping the protein universe. Science 273, 595-603.

38) Yokoyama, H., Fujii, S. and Matsui, I. (2008) Crystal structure of core domain of stomatin from Pyrococcus horikoshii illustrates a novel trimeric and coiled-coil fold. J. Mol. Biol. 376, 868-878.

39) Tavernarakis, N., Driscoll, M. and Kyrpides, N.C. (1999) The SPFH domain: implicated in regulating targeted protein turnover in stomatins and other membrane-associated proteins. Trends Biochem. Sci. 24, 425-427.

40) Umlauf, E., Csaszar, E., Moertelmaier, M., Schuetz, G.J., Parton, R.G. and Prohaska, R. (2004) Association of stomatin with lipid bodies. J. Biol. Chem. 279, 23699-23709.

41) Huber, T.B., Schermer, B., Müller, R.U., Höhne, M., Bartram, M., Calixto, A., Hagmann, H., Reinhardt, C., Koos, F., Kunzelmann, K., Shirokova, E., Krautwurst, D., Harteneck, C., Simons, M., Pavenstädt, H., Kerjaschki, D., Thiele, C., Walz, G., Chalfie, M. and Benzing, T. 
(2006) Podocin and MEC-2 bind cholesterol to regulate the activity of associated ion channels. Proc. Natl. Acad. Sci. U.S.A. 103, 17079-17086.

42) Kickhoefer, V.A., Stephen, A.G., Harrington, L., Robinson, M.O. and Rome, L.H. (1999) Vaults and telomerase share a common subunit, TEP1. J. Biol. Chem. 274, 32712-32717.

43) Poderycki, M.J., Rome, L.H., Harrington, L. and Kickhoefer, V.A. (2005) The p80 homology region of TEP1 is sufficient for its association with the telomerase and vault RNAs, and the vault particle. Nucleic Acids Res. 33, 893-899.
44) Goldsmith, L.E., Yu, M., Rome, L.H. and Monbouquette, H.G. (2007) Vault nanocapsule dissociation into halves triggered at low $\mathrm{pH}$. Biochemistry 46, 2865-2875.

45) Grimsley, G.R., Scholtz, J.M. and Pace, C.N. (2009) A summary of the measured $\mathrm{pK}$ values of the ionizable groups in folded proteins. Protein Sci. 18, $247-251$.

(Received May 25, 2012; accepted July 20, 2012)

\section{Profile}

Tomitake Tsukihara was born in 1944. After graduating from the School of Pharmaceutical Sciences at Osaka University, he went on to conduct graduate study at the Institute for Protein Research at Osaka University. As a graduate student, he performed a crystallographic analysis of cytochrome c. He moved to Tottori University in 1971, and determined the crystal structure of [2Fe-2S] ferredoxin in 1980.

Since then, he has performed pioneering work in the structural study of biological macromolecular assemblies, including membrane proteins. He was promoted to Professor at the University of Tokushima in 1991 and moved back to the Institute for Protein Research at Osaka University in 1995. He determined the structure of bovine cytochrome c oxidase in collaboration with Prof. Shinya Yoshikawa of the University of Hyogo in

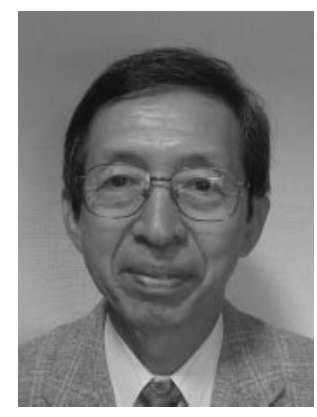
1995. His high-resolution structural studies of the cytochrome c oxidase are aimed at elucidating the mechanism of proton pumping coupled with dioxygen reduction.

He determined the structures of the mammalian $20 \mathrm{~S}$ proteasome, a double-shelled Rice dwarf virus and protein complexes involved in intracellular transport, including the Importin- $\beta$ :SREBP complex, the Exportin5:RanGTP:pre-miRNA complex, the Connexin-26 gap junction channel and vault.

Prof. Tsukihara was awarded the 1987 prize from the Crystallographic Society of Japan; the 1996 Amgen Prize from the Protein Society (U.S.A.); the 2004 prize from the Ministry of Education, Culture, Sports, Science and Technology of Japan; and the 2010 Nishikawa Award from the Crystallographic Society of Japan. He has served as the Director of the Institute for Protein Research at Osaka University from 2006 to 2008. He has served as the president of the Crystallographic Society of Japan (2006-2008) and the president of the Protein Society of Japan (2008-2010). 